\title{
Monks, Aristocrats, and Justice: Twelfth-Century Monastic Advocacy in a European Perspective
}

\author{
By Charles West
}

\section{INTRODUCTION}

Around the year 1250, the Bavarian monk Hermann of Niederaltaich composed a short treatise about the aristocrats who had served as advocates (advocati) for his monastery. As well as providing a potted history reaching back into the tenth century, Abbot Hermann earned future historians' gratitude by explaining very clearly why monasteries like his needed these figures in the first place. There were, he wrote, many reasons, but he picked out two: churches needed advocates to protect their lands, and they needed advocates for the exercise of justice. "For," explained Hermann, "it does not pertain to clerical dignity to exercise judgment of blood," so dealing with theft, murder, rape, and other capital offences required a layman's involvement. ${ }^{1}$

Hermann was of course writing for a particular purpose, and his relatively short treatise, De advocatis Altahensibus, did not circulate widely. It is nevertheless an often-cited work, since it is one of the few medieval texts to provide an overview of a topic that historians have long recognized to be of great importance. ${ }^{2}$ Advocates such as those of Niederaltaich were a familiar part of aristocratic society in central medieval Germany, and though they seldom received such focused treatment as that provided by Hermann, they make frequent appearances in monastic history writing, and indeed in other monastic textual productions, such as letters and, above all, charters, as we shall see. They loom large too in modern research, since the advocacy of monasteries such as Hermann's is acknowledged to have

I am grateful to Julia Barrow, Liesbeth van Houts, Emma Hunter, and Thomas Kohl for advice on a draft of this paper, the research for which was enabled by an Arts and Humanities Research Council Early Career Fellowship, AH/L010623/1, and further supported by a Humboldt Fellowship held at the University of Tübingen. I am also grateful to audiences in Oxford and Namur and to the anonymous reviewers of this journal for their perceptive and helpful comments. Finally, my thanks to Jennifer Davis, Denis Drumm, Jamie Irvine, Simon John, Jonathan Lyon, Alyx Mattison, Herold Pettiau, and Andrea Stieldorf for discussion, suggestions, and sharing of forthcoming work. All hyperlinks accessed 16 November 2016.

${ }^{1}$ Hermann of Niederaltaich, De advocatis Altahensibus, ed. Philip Jaffé, MGH SS 17 (Hannover, 1861), 373, "Item quia non est clericalis dignitatis, iudicium vel vindictam sangwinis [sic] exercere."

${ }^{2}$ The treatise survives only in Munich, Bayerisches Hauptstaatsarchiv, MS Kloster Niederaltaich Lit. No. 39, a manuscript put together on Hermann's instructions around 1254: see Josef Klose, Die Urkunden Abt Hermanns von Niederaltaich (1243-1273) (Munich, 2010), 52*-53* (separate pagination), and Klose, Das Urkundenwesen Abt Hermanns von Niederalteich (1242-1273): Seine Kanzlei und Schreibschule (Kallmünz, 1967), 18-20. Jonathan Lyon, "Noble Lineages, Hausklöster, and Monastic Advocacy in the Twelfth Century: The Garsten Vogtweistum in Its Dynastic Context," Mitteilungen des Instituts für Österreichische Geschichtsforschung 123 (2015): 1-29, describes Hermann's text "as one of the best surviving medieval descriptions of the role of the monastic advocate," while drawing attention to the abbot's contemporary difficulties with the advocates of Mintraching as a relevant context for its composition. 
been a key source of political and social power for elites in the Reich; and after a period of relative neglect, the topic is coming back into fashion. ${ }^{3}$

Hermann would have found much of this research familiar in its outlines, for it has largely followed his lead in emphasizing political protection on the one hand and judicial functions on the other. ${ }^{4}$ And yet in another sense, Hermann's text is wholly at odds with this analysis. What Hermann wanted to explain was why monasteries like his needed advocates; but most historians who have studied these advocates have tended to approach the matter quite differently. They have usually presumed an antagonistic relationship between monastic community and predatory advocate, tracking how the former, inspired by monastic or Gregorian reform, resisted claims opportunistically pressed by the latter. ${ }^{5}$ Much of the more recent work has been carried out in the course of studies of regional aristocracies, in the tradition of Landesgeschichte, and with the purpose of showing how noble families exploited advocacy in pursuit of their interests.

Thinking of monastic advocacy primarily as an instrument for the consolidation of aristocratic power (Herrschaftsbildung) is far from unreasonable, since it often demonstrably did perform this role. But this focus has led to the neglect of a crucial feature of monastic advocacy, namely its geography. Aristocrats were closely involved with monasteries at a number of levels everywhere in the central Middle Ages, but monastic advocacy of the kind that Hermann discussed was particular to the Reich, and was found seldom, or only in less developed form, elsewhere in the Latin West. ${ }^{6}$ The perspective that prioritizes how aristocrats harnessed advocacies has not however encouraged investigation of this issue, if only

\footnotetext{
${ }^{3}$ The Konstanzer Arbeitskreis and the University of Namur have both recently held conferences on ecclesiastical advocacy in the Middle Ages, with publication anticipated. Meanwhile, Jonathan Lyon is currently working on the topic as well: see Jonathan Lyon, "Otto of Freising's Tyrants," in Christianity and Culture in the Middle Ages: Essays to Honor John Van Engen, ed. David C. Mengel and Lisa Wolverton (Notre Dame, 2013), 141-67, and "Noble Lineages," with ample references to the "innumerable German and Austrian studies" of the nineteenth and twentieth centuries. For a recent German summary, see Martin Clauss, Die Untervogtei: Studien zur Stellvertretung in der Kirchenvogtei im Rahmen der deutschen Verfassungsgeschichte des 11. und 12. Jahrbunderts (Siegburg, 2002). As an example of the older literature, see Hermann Aubin, Die Entstehung der Landeshoheit nach niederrheinschen Quellen: Studien über Grafschaft, Immunität und Vogtei (Berlin, 1920).

${ }^{4}$ For example, Hans Hirsch, Die Klosterimmunität seit dem Investiturstreit: Untersuchungen zur Verfassungsgeschichte des deutschen Reiches und der deutschen Kirche (Cologne, 1967), 66, drawing on Hermann's text.

${ }^{5}$ In the words of Lyon, "Otto of Freising's Tyrants," 155, seeing how advocates used their position "to advance their own interests and those of their families." See also Benjamin Arnold, Princes and Territories in Medieval Germany (Cambridge, UK, 2003), 196, concentrating on "the ways in which the secular aristocracy used and abused this power in order to improve their own status and revenues." This is also the case in more recent English scholarship on "violent lordship": see Thomas N. Bisson, The Crisis of the Twelfth Century: Power, Lordship and the Origins of European Government (Princeton, 2009), which integrates advocates into a wider narrative about violence and accountability, e.g., 153-54: "This advocacy was a hereditary lordship"; see also 225 and 317, and s.v. "advocate" in index, 641. See below, 394-95.

${ }^{6} \mathrm{~A}$ key article in setting out the importance of aristocratic relations with monasteries was John Howe, "The Nobility's Reform of the Medieval Church," American Historical Review 93 (1988): 317-39. For the association of advocacy with the Reich, see Clauss, Untervogtei, 281-87, and Lyon, "Otto of Freising's Tyrants."
}

Speculum 92/2 (April 2017) 
because it is difficult to study an absence. To the extent that the geography of advocacy has been considered within this scholarship, it has been assumed to reflect some innate quality inhering in the Germanic aristocracy that predisposed it to this practice. ${ }^{7}$

This article takes a different view. With a focus on the decades around 1100, it pays particular attention to the judicial dimension of monastic advocacy, more clearly defined than the generic protection or political patronage universally sought by monastic communities everywhere in the Latin West; and it concentrates on old, wealthy, and well-established Benedictine communities, leaving to one side other forms of advocacy, notably those relating to bishops and to the emerging Cistercian group of monasteries. ${ }^{8}$ Above all, instead of concentrating on what aristocratic families did with their monastic advocacies, it looks at what monastic communities in the Reich did with their advocates, and how comparable communities elsewhere managed without them.

Examined in this way, it becomes clear that monastic advocacy was a product not simply of aristocratic power, as has usually been supposed, tacitly or otherwise, but also of the perceived needs of certain monastic communities. It was therefore religious as much as political, part of the debates as to how the monastic vocation of turning away from the world should best be fulfilled in everchanging conditions. In this sense, the study of advocacy confirms the importance of taking a European-wide approach, or at least an approach transcending the boundaries of any one country, modern or medieval, if historians are to understand any particular aspect of the Middle Ages; and the urgency of integrating religion back into political and social history if we are to understand the interplay of these dimensions. ${ }^{9}$

\section{Monastic Advocates in the Twelfth-Century Reich}

As already mentioned, Hermann of Niederaltaich's De advocatis Altahensibus is an unusual text. This is partly a question of its clarity, and partly too a question of its date, for as an issue that commanded contemporaries' attention, monastic advocacy in post-Carolingian Europe was a predominantly twelfth-century phenomenon (though in certain regions it survived late into the Middle Ages in

\footnotetext{
${ }^{7}$ The most important explicitly comparative study remains Theodor Mayer, Fürsten und Staat: Studien zur Verfassungsgeschichte des deutschen Mittelalter (Weimar, 1950), who points to a contrast between Roman and Germanic ways of thinking, or Denkweise (18); see also discussion of the "rein germanischen Ländern" (1) and of the importance of the "germanische Adel" (19).

${ }^{8}$ Episcopal advocacy has been less studied than monastic advocacy, though it presents very interesting questions. See, however, Joseph Milz, "Die Vögte des Kölner Domstiftes und der Abteien Deutz und Werden im 11. und 12. Jahrhundert," Rheinische Vierteljahrsblätter 41 (1977): 196-217. On the Cistercians, see below, note 142 .

${ }^{9}$ On the importance of, and obstacles faced by, working towards a properly European historiography of the Middle Ages, see Bernhard Jussen, "Diskutieren über Könige im vormodernen Europa: Einleitung," in Die Macht des Königs: Herrschaft in Europa vom Frühmittelalter bis in die Neuzeit, ed. Bernhard Jussen (Munich, 2005), esp. xi-xiv. On the religious perspective, see note 149 below.
}

Speculum 92/2 (April 2017) 


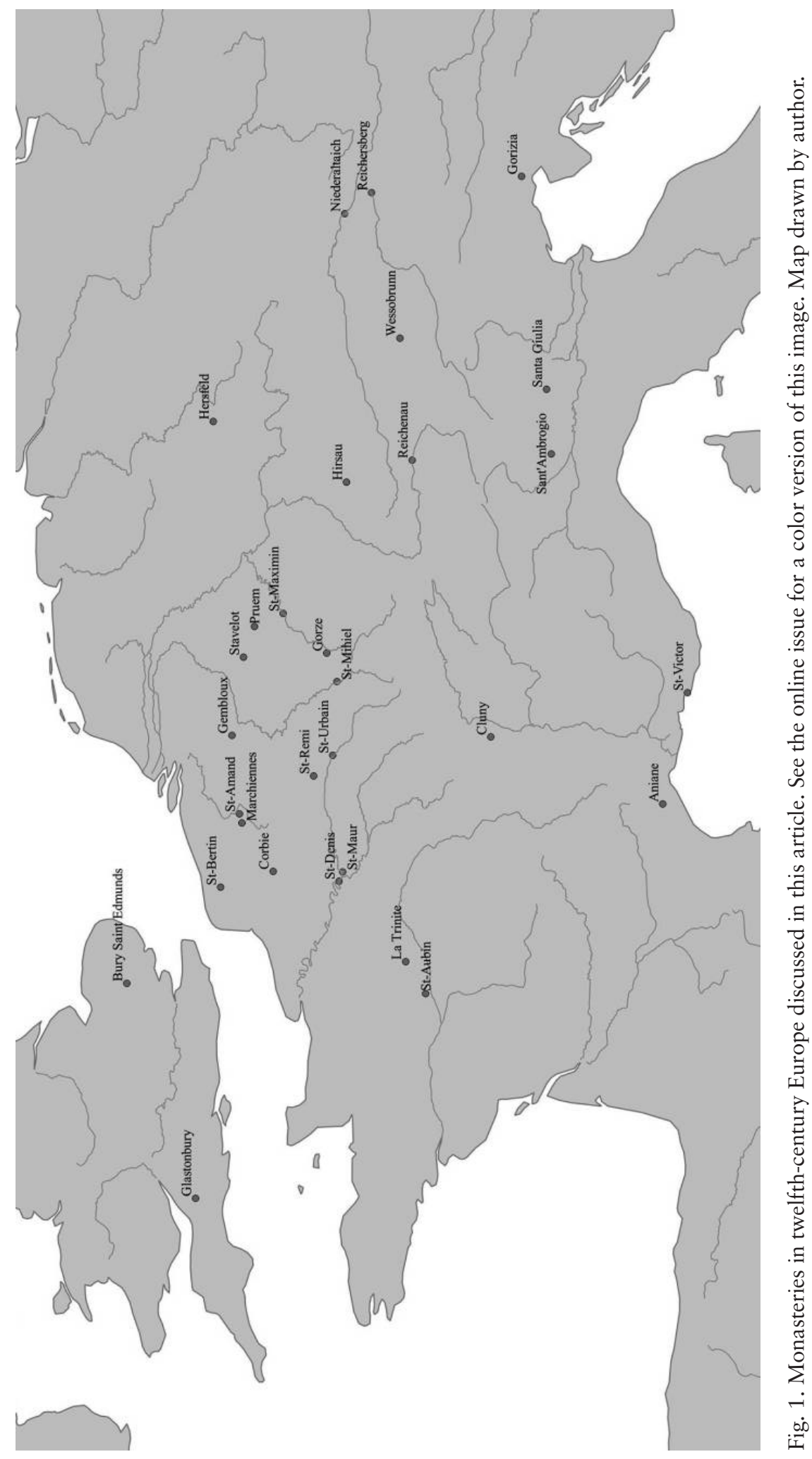

This content downloaded from 143.167.030.213 on May 23, 2017 06:59:03 AM All use subject to University of Chicago Press Terms and Conditions (http://www.journals.uchicago.edu/t-and-c). 
residual form). ${ }^{10}$ Above all, though, De advocatis is unusual insofar as most of what we know about monastic advocacy comes not from narratives of this kind, nor from letters, hagiography, or liturgical sources-though all these genres do make significant contributions-but from charters. ${ }^{11}$ The archives of monasteries across the Reich, from the Rhineland to Swabia, Lotharingia to Bavaria (though unfortunately not Niederaltaich, whose pre-1200 records are fragmentary), preserve a stately body of documentation in the shape of scores of charters defining what monastic advocates could and could not do in the decades around 1100, often in significant detail. ${ }^{12}$

It is these charters, noticeably filling out from the later eleventh century, that have served as the basis for a vast and impressive literature on monastic advocacy, and this study too will rely chiefly upon them. ${ }^{13}$ Most of these texts are well known to specialists and have been studied in their local context, as part of surveys of regions or of individual monasteries and their relations with aristocratic families. Recently, however, and remarkably, an entirely fresh set of texts that deal with advocacy in the twelfth century has emerged: and it is with these that we shall begin, since they offer a useful introduction for those unfamiliar with what monastic advocacy entailed.

${ }^{10}$ For monastic advocacy's continued importance in Swabia into the early modern period, see Wilhelm Liebhart, “' 'advocatiae super possessiones beati Udalrici': Zur mittelalterlichen Klostervogtei in Schwaben und Baiern am Beispiel von St. Ulrich und Afra," in Aus Schwaben und Altbayern: Festschrift für Pankraz Fried zum 60. Geb., ed. Peter Fassl, Wilhelm Liebhart, and Wolfgang Wüst (Sigmaringen, 1991), 169-77. This article does not deal with Carolingian advocacy in the light of the arguments for discontinuity set out in Charles West, "The Significance of the Carolingian Advocate," Earlv Medieval Europe 17 (2009): 186-206.

${ }^{11}$ A good example of a letter is that from Abbot Folcard of Lobbes to Emperor Henry IV, c. 1101, preserved in Wilhelm Arndt, ed., Gesta Abbatum Lobiensium, MGH SS 21 (Hannover, 1869), 31416. For an example of hagiography, see note 89 and the remarkable poem by Metellus of Tegernsee, Die Quirinalien des Metellus von Tegernsee: Untersuchungen zur Dichtkunst und kritische Textausgabe, ed. Peter Jacobsen (Leiden, 1965). For an example of a liturgical source referring to advocates, see Francesco Roberg, Gefälschte Memoria: Diplomatisch-Historische Studien zum ältesten "Necrolog” des Klosters St. Maximin vor Trier, MGH Studien und Texte 43 (Hannover, 2008), esp. 49-51. A wide-ranging summary is provided by Andrea Stieldorf, "Klöster und ihre Vögte zwischen Konflikt und Interessenausgleich im 11. und 12. Jahrhundert," Vorträge und Forschungen, forthcoming.

${ }^{12}$ For Lotharingia, see Egon Boshof, "Untersuchungen zur Kirchenvogtei in Lothringen im 10. und 11. Jahrhundert," Zeitschrift der Savigny-Stiftung für Rechtsgeschichte: Kanonistische Abteilung 65 (1979): 55-119; and Michel Parisse, ed., L'avouerie en Lotharingie: Actes des 2es Journées Lotharingiennes, 22-23 oct. 1982 (Luxembourg, 1984). For the Upper Rhine, see Thomas Zotz, "Zur Bedeutung von Kirche und Klostervogtei für Grafen und Herren: Oberrheinische Beispiele aus dem Hoch- und Spätmittelalter," in Grafen und Herren in Südwestdeutschland vom 12. bis ins 17. Jahrhundert, ed. Kurt Andermann and Clemens Joos (Epfendorf, 2006), 155-68. For the lower Rhine, in addition to Aubin, Entstehung, see Heinz Finger, "Das Kloster und die Vögte: Die 'Schutzherren' von Werden," in Das Jahrtausend der Mönche: Klosterwelt Werden 799-1803, ed. Jan Gerchow (Cologne, 1999), 99-105. On the archive of Niederaltaich, see Klose, Urkunden, 29*-35*. Saxony is the German region with the least forthcoming evidence, but a recent investigation into a Saxon advocatial family is provided by Ellen Widder, "Symbiose und Konkurrenz: Eine verfassungsgeschichtliche Fallstudie zum westfälischen Adel im Hochmittelalter," Westfälische Forschungen 44 (1994): 367-447.

${ }^{13}$ On the periodization of the charters, see Theo Kölzer, Studien zu den Urkundenfälschungen des Klosters St. Maximin vor Trier (10.-12. Jahrhundert) (Sigmaringen, 1989), esp. 261-303. For a critique of the way in which charters have been unduly privileged as sources, see Lyon, "Noble Lineages" (though even this study makes good use of them, alongside other texts).

Speculum 92/2 (April 2017) 


\section{Reichenau}

In 2010, Rudolf Pokorny published a number of early modern transcriptions that had been discovered, and promptly set aside, in the course of a previous study of the scholar responsible for making them. ${ }^{14}$ The scholar in question, Konrad Peutinger, best known today for his celebrated copy of a Roman road map, had access in the early sixteenth century to now-lost texts from the island monastery of Reichenau in Swabia (southwestern Germany) that he collected for a planned book on imperial history. Some of the texts uncovered by the research into Peutinger were previously known to historians only in early modern German translation; a number were unknown in their entirety. Together, they shed light on the work of an unnamed forger who worked at the monastery under Abbot Udalric II in the early twelfth century and whose work focused on the monastery's advocates. ${ }^{15}$

The most exciting discovery among Peutinger's transcriptions, however, is not a forgery but a genuine charter issued in the name of Abbot Udalric II around 1100 . It begins with a lament about monastic advocates "who in no way behaved like subjects and faithful followers, but wished to be served upon like kings." ${ }^{16}$ The abbot declared that he was taking the opportunity presented by the death of Reichenau's advocate Hermann (recently assassinated by the monastery's knights) to grant the advocatia of the monastery to an aristocrat named Arnold of Goldbach. The abbot's grant came, however, with certain conditions, based on previous privileges but also on ancient custom (longevo usu), that the charter then set out. The advocate was not allowed to exercise any judicial authority on the island of Reichenau itself unless requested by the abbot; he was to hold annual judicial assemblies only at three specified locations off the island, or, by arrangement with the abbot, at a fourth location. Allowances in kind were determined for each assembly. Revenues from these placita were split unequally between abbot and advocate, and servants (servientes) of the monastery were exempted from the advocate's authority unless requested by the abbot. The advocate was not to appoint a deputy (a subadvocate) without the abbot's permission or to demand gifts as if they were owed. If any of these rules were broken, the penalty was loss of the advocacy.

These conditions are typical of hundreds of similar charters issued throughout the Reich: of common elements, only military service and fortification work were missed out. When looking at documents such as these, historians have focused on how they were intended as weapons against the advocate. That perspective can be justified in this case, as in others. Not long after this text was drawn up,

\footnotetext{
${ }^{14}$ Rudolf Pokorny, Augiensia: Ein neuaufgefundenes Konvolut von Urkundenabschriften aus dem Handarchiv der Reichenauer Fälscher des 12. Jahrhunderts, MGH Studien und Texte 48 (Hannover, 2010).

15 This forger was first identified by Johann Lechner, "Schwäbische Urkundenfälschungen des 10. und 12. Jahrhunderts," Mitteilungen des Instituts für Österreichische Geschichtsforschung 21 (1900): 28-106. Earlier and later forgers had different targets: Pokorny, Augiensia, provides a concise discussion, 7-9. A general background is provided by Helmut Maurer, ed., Die Abtei Reichenau: Nene Beiträge zur Geschichte und Kultur des Inselklosters (Sigmaringen, 1974).

${ }^{16}$ Pokorny, Augiensia, no. 32, 139-45, at 139.
} 
the Reichenau forger used it as a template to create falsified documents for the monastery in the names of the emperors Charlemagne and Arnulf. ${ }^{17}$ The aim was not necessarily to concoct false legal "proof," for the new charters could have been intended simply to convince the advocate of the rightness of the monastery's cause, or even to stiffen the community's nerves: an advocate claiming more than the 1100 charter permitted would have found himself facing a monastic community confident that their demands were genuinely rooted in an ancient past. ${ }^{18}$

Yet we should note that the Reichenau charters, even the forgeries, did not actually deny the legitimacy of their advocate's powers, if properly exercised. By projecting contemporary conditions back into the Carolingian age, a time when advocates had actually played a far less powerful role, the Reichenau forger constrained the advocate's powers; but he also legitimated them, anchoring their exercise in a distant and authoritative past. The Reichenau monks were not simply opposed to advocates: after all, this was an institution where just a few decades previously, an advocate had taken laudably decisive action against a corrupt and simoniacal would-be abbot. ${ }^{19}$ Rather than merely monastic weapons aimed at avaricious aristocrats bent on taking advantage of royal or imperial weakness to impose themselves on neighboring monasteries, these texts were resources for negotiations, negotiations in which the monks played a leading, active role.

\section{Saint-Mibiel}

If they wanted to make changes to the relationship with their advocate, it was not always necessary for monks to resort to outright and wholesale forgery. A good illustration is furnished by a text roughly contemporary to that of Abbot Udalric II but produced some three hundred miles away, on the river Meuse. In 1135 , the abbot of Saint-Mihiel issued a charter concerning the advocacy of lands at Condé-sur-Meuse. ${ }^{20}$ Surviving in its original form, this text sets out, in ways comparable to that of Reichenau, the dues, obligations, and rights of an advocate, though in this case concerning just one of the monastery's estates. The advocate, Guido, was to play a role in judicial matters only on the invitation of the abbot and the provost, in which case he was entitled to a third of the judicial proceeds, and the fines were to be set by monastic officials, namely the villicus and the scabinus. Duels were to take place under the advocate's supervision within the village itself, not at his residence, and they were only to be held after the abbot had attempted to resolve the dispute peacefully. The circumstances of the advocate's military assistance were also carefully established, with details given of the

\footnotetext{
${ }^{17}$ Pokorny, Augiensia, no. 5, 29-36, and no. 9, 46-51, supersedes all previous editions.

${ }^{18}$ On monastic communities, see Steffen Patzold, Konflikte im Kloster: Studien zu Auseinandersetzungen in monastischen Gemeinschaften des ottonisch-salischen Reichs (Husum, 2000). For monastic appropriations of the past, see the classic Amy G. Remensnyder, Remembering Kings Past: Monastic Foundation Legends in Medieval Southern France (Ithaca, 1995), as well as Constance B. Bouchard, Rewriting Saints and Ancestors: Memory and Forgetting in France, 500-1200 (Philadelphia, 2014).

${ }^{19}$ Lampert of Hersfeld, Annales, ed. Oswald Holder-Egger; Lamperti monachi Hersfeldensis Opera, MGH SS rer. Germ. 38 (Hannover, 1894), 171 (for the year 1071).

${ }^{20}$ The text is edited in André Lesort, ed., Chronique et chartes de l'abbaye de Saint-Mibiel, Mettensia 6 (Paris, 1909-12), no. 79 (279-83).
}

Speculum 92/2 (April 2017) 
support he could expect from the monastery's estates. Finally, the advocate was declared to be entitled to no more than three expenses-paid visits to Condé a year.

The text may seem perfectly clear, but to be understood properly it must be read in the context of two previous charters that also addressed the advocacy of Condé. In 1091, a charter had been put together on the death of the advocate (as at Reichenau) before the position was confirmed to the heir, Liethard. When on Liethard's death the advocacy passed to Guido in 1116, the monks produced a revised document that made a number of small changes. The community now accepted the advocate's rights to supervise the duel, the advocate's rights to reside in the village were increased from "once or twice" to "twice or three times," and the whole agreement was now guaranteed by the count of Bar and his court, charged with correcting any infractions of the agreement; the witnessing by inhabitants of Condé that had taken place in 1091 was apparently no longer necessary. ${ }^{21}$

The charter of 1135 was explicitly a revision of this 1116 agreement, for its preface states that Guido had "not rightly understood the meaning in some places" of the 1116 charter, having demanded more than was permitted, and that the opportunity was now being taken to clarify matters. Most historians have believed that the monks then proceeded simply to recopy out the 1116 text again. This is an entirely understandable conclusion to draw, not least because the 1135 charter was made to look physically very similar to its precursor. ${ }^{22}$ Nevertheless, on close inspection there are clear signs of tiny but meaningful changes to the text. For instance, in one phrase, a single word was moved:

1119 text: Sic tertiam partem summae et districtum suum, id est duos nummos, accipiet. 1135 text: Sic tertiam partem summae et districtum suum accipiet, id est duos nummos. ${ }^{23}$

We may suppose that Guido had understood the twopence (duos nummos), perhaps tendentiously, to cap only the districtum, and not the "third part" as well. Other minor changes clarified that payments were to the advocate alone, and that all military equipment lent to the advocate for military expeditions was to be returned after the expedition was completed. ${ }^{24}$ It is implausible that these changes, which together significantly alter the meaning of the text, are innocent slips of the pen, not least because the rest of the charter is identical to the letter, and moreover follows the explicit statement that the charter would be rewritten "in clearer words." ${ }^{25}$ These changes presumably reflect the disputed points that the Condé advocate had "not rightly understood."

${ }^{21}$ Lesort, Chronique et chartes, no. 50 (181-85), and no. 64 (228-31).

${ }^{22}$ For instance, Anja Gillen, St. Mibiel im hohen und späten Mittelalter: Studien zu Abtei, Stadt und Landesherrschaft im Westen des Reiches, Trierer historische Forschungen (Trier, 2003), 135-36, describing the 1135 charter as a "taktischen Pflichtübung." All three charters are kept in Archives

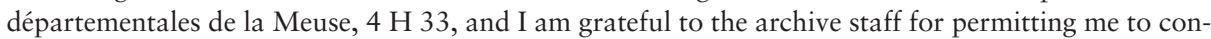
sult the originals. The text of the 1091 and 1116 charters can now be accessed via the Artem database of original charters preserved in France as nos. 117 and 121, respectively, at http://www.cn-telma.fr /originaux/.

23 "Thus he will take the third part of the sum and his districtum, that is twopence."

${ }^{24}$ A further difference between the two texts as published in Lesort, Chronique et chartes, namely profectio for perfectio (230 and 281), is merely a transcription error, and it should read perfectio in both. A small number of insignificant changes were made, such as ipsius for illius, idem for ipse.

25 "Verbis apertioribus," Lesort, Chroniques et chartes, 280. 
The advocacy at Condé then was shaped by texts, as the monks of Reichenau hoped their advocacy would be too. At around the same time, another advocate, Berthold, mockingly declared to the monks of Prüm in the Ardennes that anyone's pen could write anything, but he was not going to lose his rights for that reason. ${ }^{26}$ The outcome of the case proved Berthold's prediction wrong, yet he was surely right in his implication that monks were far from passive. Through texts, they negotiated the exercise of particular powers with certain families. The monks at Saint-Mihiel and Reichenau were clearly attempting to reduce these powers overall, and made the most of their mastery of record keeping to do so, in ways that may seem now to be deceitful. It is therefore all the more striking that they did not fundamentally reject the advocate's claims but were satisfied with contesting certain details.

\section{Advocacy across the Reich}

As can already be seen from the two cases discussed above, advocacy agreements were always tailored to some degree to each monastery, so there is considerable variation from charter to charter, from institution to institution. But though generalization always brings inaccuracy, it is evident, and worth emphasizing, that monastic advocacy across the Reich had plenty of shared features, including, perhaps especially, the question of the exercise of justice, in almost every case delegated to some degree by the monks to the advocate. Contemporaries were evidently well aware that different advocacies had much in common with one another. The Reichenau forger produced charters about advocacy for other monasteries in the region, all based on the Reichenau template, and a forger at St. Maximin in Trier (on whom more below) similarly prepared advocacy regulation texts for several institutions around $1115 .{ }^{27}$ Clearly there was enough common ground for "best practice" about advocacy to be transferable between different communities, irrespective of local specificity.

This common ground also led to occasional efforts to regulate monastic advocacy at a wider level, beyond the case-by-case approach represented by most charters (and chronicles). For example, canons from a provincial council held at Salzburg in 1216, preserved in a single manuscript now in Munich (Bayerische Staatsbibliothek, MS Clm. 5822), record that the council issued two regulations about advocacy that implicitly applied across the whole archdiocese: that no advocate should take more from church property "than ancient custom reasonably permits," and that if a church had charters defining the rights of its advocates, any breach of these rights should be met with excommunication. ${ }^{28}$

\footnotetext{
${ }^{26}$ Dietrich von Gladiss and Alfred Gawlik, eds., Die Urkunden Heinrichs IV, MGH DD H IV, 3 vols. (Berlin, Weimar, Hannover, 1941-78), vol. 2, no. 476 (647-50): "irridens testamenta dicensque penna cuiuslibet quelibet notare posset, non ideo suum ius amittere deberet," 648-49. The charter is undated, but must be early twelfth century: see Kölzer, Urkundenfälschungen, 267-69.

${ }^{27}$ Reichenau: Lechner, "Urkündenfälschungen.” St. Maximin: Kölzer, Urkundenfälschungen, 16061. See below, 391, for a parallel example of the circulation of advocacy charters in Flanders around the same time.

${ }^{28}$ Quoted in Paul Pixton, The German Episcopacy and the Implementation of the Decrees of the Fourth Lateran Council, 1216-1245: Watchmen on the Tower (Leiden, 1995), 231 (with n. 34). Advocates
}

Speculum 92/2 (April 2017) 
At a still larger scale, kings and emperors too perceived monastic advocacy as something widely spread across the Reich as a whole and treated it as such. Whether decrees about it issued by Emperor Henry IV in 1099 and in 1104 were quite as wide reaching as nineteenth-century historians imagined is not clear, but by the mid-twelfth century there is less room for ambiguity. ${ }^{29}$ In 1152, Emperor Frederic Barbarossa's Landfrieden allowed for advocates to lose their advocacies if they mistreated them. ${ }^{30}$ Just three years later, Frederic issued a charter for the monastery of Wessobrunn (Bavaria), and though this was a privilege for a specific institution, Frederic claimed in the document that his imperial predecessors Henry V, Lothar III, and Konrad III had all protected churches from advocates, and declared that the "judgment of our court" (iudicium curie nostri) was no different. In other words, Frederic asserted that there was a coherent position on the issue across generations of rulers, and across the empire. ${ }^{31}$ Given the frequency with which he encountered advocacy-over a quarter of his surviving charters deal with it in some way-this ought not to surprise us. ${ }^{32}$ Moreover, from the early twelfth century emperors began to emphasize the notion that all advocates owed their authority to the emperor himself, a concept known as the Bannleihe. The spread of this way of seeing things was perhaps as much due to monastic networks as imperial decree, but the effect was nevertheless to create a space of shared practice. ${ }^{33}$

People outside the Reich also recognized that advocacy was an institution or set of practices that especially mattered there. Papal charters from the mid-eleventh century often included references to advocacy, but in general only for recipients within the empire. ${ }^{34}$ It is true that the Council of Reims in 1148 declared no ad-

were also discussed in other thirteenth-century German councils: see Joseph Hartzheim, ed., Concilia Germaniae, 4 vols. (Cologne, 1760), 3:533 (Trier, 1227) and 655 (Salzburg, 1281).

${ }^{29}$ Frutolf of Michelsberg, Chronicon, ed. and trans. Franz-Josef Schmale and Irene Schmale-Ott, Frutolfs und Ekkehards Chroniken und die anonyme Kaiserchronik, Ausgewählte Quellen zur deutschen Geschichte des Mittelalters 15 (Darmstadt, 1972), 118; MGH Constitutiones et acta publica imperatorum et regum, 12 vols. (Hannover, 1893-2013), vol. 1, no. 75 (126), and also von Gladiss and Gawlik, Die Urkunden Heinrichs IV, vol. 2, no. 482 (657-58). Both texts may have been intended only for local application, but Hermann of Niederaltaich seems to have interpreted the sententia as a general rule and copied it into his collection.

${ }^{30}$ Edited in MGH Const., vol. 1, no. 140 (194); see now, though, Heinrich Appelt, ed., Die Urkunden Friedrichs I, MGH DD F I, 5 vols. (Hannover, 1975), vol. 1, no. 25 (39-44). See Alan Harding, Medieval Law and the Foundations of the State (Oxford, 2002), 91-93.

${ }^{31}$ Edited in MGH Const., vol. 1, no. 157 (219); see now, though, Appelt, Die Urkunden Friederichs I, vol. 1, no. 125 (210-11).

${ }^{32}$ For the statistic, Sabine Penth, "Kloster- und Ordenspolitik der Staufer als Gegenstand einer vergleichenden Ordensforschung: Das Beispiel der Prämonstratenser, die Vogteiregelungen Friedrich Barbarossas und viele offene Fragen," Analecta Praemonstratensia 81 (2005): 64-93, at 80. Penth counted 1,031 charters, of which 286 concerned advocacy.

${ }^{33}$ The classic work is Robert Scheyhing, Eide, Amtsgewalt und Bannleihe: Eine Untersuchung zur Bannleihe im hohen und späten Mittelalter (Cologne, 1960). Denis Drumm, Das Hirsauer Geschichtsbild im 12. Jahrhundert: Studien zum Umgang mit der klösterlichen Vergangenheit in einer Zeit des Umbruchs (Ostfildern, 2016), argues that the celebrated Hirsau charter of 1075 is really an early twelfth-century forgery, which effectively postpones the emergence of the Bannleibe by a decade or so.

${ }^{34}$ Raissa Bloch, "Die Klosterpolitik Leos IX in Deutschland, Burgund und Italien," Archiv für Urkundenforschung 11 (1930): 176-257.

Speculum 92/2 (April 2017) 
vocate should dare to take or accept anything beyond what was permitted by ancient custom, without specifying that this applied to any particular geographical context. ${ }^{35}$ Nevertheless, it has been pointed out that on that same day the pope had issued two charters for two monasteries within the Reich about advocacy, and this may have influenced matters. ${ }^{36}$ Pope Hadrian IV seems to have been more direct in the 1150 s, discussing advocacy with specific reference to circumstances "in the German kingdom" (in teotunico regno). ${ }^{37}$ And the Fourth Lateran Council of 1215, which demanded that advocati should take no more than was due to them by right, identified the problem as one that affected "certain ecclesiastical provinces." 38

\section{Monasteries and the Administration of Justice outside the Reich, 1: ENGLAND AND NORTHERN ITALY}

It should by now be apparent that monastic advocacy was a phenomenon that took different forms in different settings within the Reich but that was nevertheless recognizably widespread. Precisely what was entailed varied from case to case, as the result of negotiations of which the charters that are our main record were themselves a part, but the general parameters were stable. In particular, there was an emphasis on limiting, but also legitimating, the rights of certain laymen to exercise judicial power over the inhabitants of monastic property. Yet as we have seen, there are also hints that monastic advocacy was quite specific to the Reich. How, then, did roughly comparable monasteries elsewhere deal at this time with the administration of justice that was the concern of advocates in the German empire?

\section{England}

Studying the ways in which communities of monks engaged with secular law in pre-Conquest England is difficult, because the evidence is scanty and, moreover, overwhelmingly skewed by the events of the Conquest itself, which provided both cause and opportunity for monasteries to rethink and redocument their position. ${ }^{39}$

\footnotetext{
${ }^{35}$ Council of Reims, 1148, chapter 6: Giovanni Mansi, ed., Sacrorum Conciliorum nova et amplissima collectio, 60 vols. (Paris, 1907-27), 21:715: "ut nullus advocatus, praeter jus et beneficium antiquitus constititum, sibi aliquid accipere vel usurpare praesumat."

${ }^{36}$ Clauss, Untervogtei, 126.

${ }^{37}$ Ibid., 129, though it should be noted that the basis for the statement is Hermann of Niederaltaich, De advocatis: MGH SS 17:374, note *.

${ }^{38}$ Antonio García García, ed., Constitutiones Concilii Quarti una cum Commentariis glossatorum (Vatican, 1981), chap. 45 (84): "in quibusdam provinciis ecclesiarum."

${ }^{39}$ The starting point for research is Patrick Wormald's landmark "Lordship and Justice in the Early English Kingdom: Oswaldslow Revisited," in Property and Power in the Early Middle Ages, ed. Wendy Davies and Paul Fouracre (Cambridge, UK, 1995), 114-36. For a rethinking of justice in early medieval England, see Thomas Lambert, "Royal Protections and Private Justice: A Reassessment of Cnut's 'Reserved Pleas," in English Law before Magna Carta: Felix Liebermann and "Die Gesetze der Angelsachsen”, ed. Stefan Jurasinski, Lisi Oliver, and Andrew Rabin (Leiden, 2010), 157-76; and Lambert, Law and Order in Anglo-Saxon England (Oxford, forthcoming). Nicole Marafioti has
}

Speculum 92/2 (April 2017) 
Such evidence as there is, however, suggests that monks in late Anglo-Saxon England, even subsequent to the Benedictine movement of the tenth century, did not occupy any privileged judicial position and were directly subjected to public courts to the same degree as everyone else. Correspondingly, royal officials in preConquest England were not impeded from access to monastic property, although on the Continent such a prohibition had been common since the seventh century. ${ }^{40}$

If that was the case, then for once the Norman Conquest really marked a significant shift. The monastery of Bury Saint Edmunds in the east of England, effectively founded in the early eleventh century but claiming a much older ancestry, provides a good example of how things worked, and how they changed. ${ }^{41}$ Before the Conquest, the monastery had obtained a whole series of royal writs from c. 1044 onwards confirming a jurisdictional exemption remarkable in Anglo-Saxon England but still very limited; these documents did not stop a royal officer from holding a court in the monastery's very precincts, and only applied to the hundred court anyway. ${ }^{42}$ By around 1100 , however, the monastery was capable of punishing petty thieves and of summoning knights to account and had produced some forged charters in the names of Kings Edmund and Cnut to beef up earlier concessions. ${ }^{43}$ More significantly, the monks had also acquired a document from King William II, c. 1087, prohibiting royal agents from entering the monastery; they soon added a charter from King Henry I, c. 1103, confirming this prohibition and

begun a new project on ecclesiastical jurisdiction in Anglo-Saxon England, which will shed much further light on the question.

${ }^{40}$ Barbara Rosenwein, Negotiating Space: Power, Restraint and Privileges of Immunity in Early Medieval Europe (Manchester, 1999), is the best general introduction to immunities, and 192-202 remains important for English circumstances. For the access prohibition, see Paul Fouracre, "Eternal Light and Earthly Needs: Practical Aspects of the Development of Frankish Immunities," in Davies and Fouracre, Property and Power, 53-61; for a different perspective, see the comments of Alexander Callander Murray, "Merovingian Immunity Revisited," History Compass 8 (2010): 913-28. For a recent analysis of English tenth-century monasticization, see Julia Barrow, "The Ideology of the Tenth-Century English Benedictine 'Reform,'” in Challenging the Boundaries of Medieval History: The Legacy of Timothy Reuter, ed. Patricia Skinner, Studies in the Early Middle Ages 22 (Turnhout, 2009), 141-54.

${ }^{41}$ An excellent introduction to Bury's general history is provided by Miracles of Saint Edmund, ed. and trans. Thomas Licence, Oxford Medieval Texts (Oxford, 2014).

${ }^{42}$ Herman and Goscelin, Miracles of Saint Edmund, ed. Licence, 10-14. The officer in question, the sheriff (vicecomes) Leofstan, is punished by the saint not for holding the court, but for breaching the monastic sanctuary by dragging a woman out from the church. The c. 1044 writ: Peter Sawyer, Anglo-Saxon Charters: An Annotated List and Bibliography (London, 1968), though now most conveniently accessed online at http://www.esawyer.org.uk/, no. 1069; edited in Anglo-Saxon Writs, ed. and trans. Florence E. Harmer (Manchester, UK, 1952), 154-55: "pa nigen half hundreda socne in to pinghogy licgce in to $\mathrm{S}$ ce Eædmunde." This text begins a sequence studied in Richard Sharpe, "The Use of Writs in the Eleventh Century," Anglo-Saxon England 32 (2003): 247-92, though he remains focused on the diplomatic aspects and is not "concerned with the nature of this liberty" (255). Sarah Foot and Kathryn Lowe, Charters of Bury St Edmunds, Anglo-Saxon Charters (Oxford, forthcoming), will set study of the pre-Conquest documents on a new footing.

${ }^{43}$ Herman, Miracles of Saint Edmund, ed. Licence, 346-48 (thief), and 64-66 (knight); Sawyer, Anglo-Saxon Charters, nos. 507 and 980. A twelfth-century manuscript, New York, Pierpont Morgan Library, MS M 736, produced at the monastery, portrays thieves being hanged at fol. $19 \mathrm{v}$ to illustrate an earlier episode of the community's history.

Speculum 92/2 (April 2017) 
also expressly commanding those who held land in the abbey's sphere of jurisdiction, the Eight and a Half Hundreds, to attend the abbot's court. ${ }^{44}$

These rights evidently meant a great deal to the Bury monks, who defended them energetically. ${ }^{45}$ Their main preoccupation may well have been freedom from the diocesan claims of successive bishops of East Anglia, but a famous dispute in 1148 shows secular justice mattered too. ${ }^{46}$ In that year, Abbot Ordring objected when a public court attempted to put some of his retinue on trial (for trying to assassinate the king, no less). ${ }^{47}$ The abbot received support from a pious elderly layman, Hervey of Glanville, who claimed that the abbot of Bury and his ministri had always dealt with all pleas that arose on the monastery's land in its own court (curia), except those about treasure and murder. The monastery continued to defend its privileges into the late twelfth and thirteenth century, stoutly rejecting the idea that anyone outside the monastery and its familia should have any involvement in the routine administration of justice. ${ }^{48}$

Another example is provided by the monastery of Glastonbury in the southwest of England. By around 1130, this monastery too rejoiced in remarkable charters issued in the names of ancient pre-Conquest kings, such as Ine, Edmund, Edgar, and Cnut. ${ }^{49}$ The charter in King Ine's name granted the abbot the powers to resolve cases of murder, theft, and rapine, among others, and forbade royal officers to enter. The text supposedly issued by King Edmund confirmed that only the abbot could determine legal questions within its lands, whether large or small, while King Edgar's diploma confirmed that the abbot's court (curia) had the same power as his own. As at Bury, all these texts are flagrant postConquest inventions (Thorpe memorably described Ine's charter as a "glaring monkish forgery"), but they nevertheless indicate what the monks thought their

\footnotetext{
${ }^{44}$ Entry prohibition issued by William II: H. W. C. Davis, ed., Regesta regum Anglo-Normannorum, vol. 1 (Oxford, 1913), no. 294; edited in David C. Douglas, ed., Feudal Documents from the Abbey of Bury St. Edmunds (Oxford, 1932), no. 15 (59), "ut nullus vestrum de illis terris et de illis hominibus amplius se si me diligitis intromittat.” Henry I: Charles Johnson and H. A. Cronne, eds., Regesta regum Anglo-Normannorum, vol. 2 (Oxford, 1956), no. 777, c. 1103x6; and edited in Douglas, Feudal Documents, no. 21 (62-63): "ut omnes libere tenentes . . veniant ad magna placita abbatis ... et qui venire noluerit distringatur."

${ }^{45}$ Sharpe, "Use of Writs," 277-79, suspects that some of the monastery's numerous post-Conquest royal writs were acquired in response to incursions, probably by royal officials.

${ }^{46}$ For the attempt of Bishop Herfast to bring the monastery under tight episcopal control, see the introduction by Licence, Miracles of Saint Edmund, xxxii-xxxiv, as well as Sarah Foot, "The Abbey's Armoury of Charters," in Bury St Edmunds and the Norman Conquest, ed. Thomas Licence (Woodbridge, UK, 2014), 31-52.

${ }^{47}$ Helen Cam, “An East Anglian Shire-Moot of Stephen's Reign," English Historical Review 39 (1924): 568-70, reedited with translation in R. C. van Caenegem, English Lawsuits from William I to Richard I, 2 vols. (London, 1990-91), 1:288-91. The famous incident is discusssed, inter alia, in Rosenwein, Negotiating Space, 196, and Kevin Shirley, The Secular Jurisdiction of Monasteries in Anglo-Norman and Angevin England (Woodbridge, UK, 2004), 47.

${ }^{48}$ Van Caenegem, English Lawsuits, 2:627-28; for the full context, see Jocelin of Brakelond, The Chronicle of Jocelin of Brakelond, ed. and trans. by H. E. Butler (Edinburgh, 1949), 50-52; see also 134-37 for a similar case around 1200 .

${ }^{49}$ See the discussion in Susan Kelly, Charters of Glastonbury Abbey, Anglo-Saxon Charters (Oxford, 2012), 124-30, with editions of the texts (nos. 11, 34, 56, and 61).
}

Speculum 92/2 (April 2017) 
rights should be. ${ }^{50}$ And again, as at Bury, there is some indication of what this meant in practice. According to William of Malmesbury, writing in the 1120s, Abbot Thurstan in 1085 had vigorously defended Glastonbury's privilege that all legal matters, secular or ecclesiastical, were at the abbot's disposition. ${ }^{51}$ It may be significant that despite his name, Thurstan was not English, and he indeed had attempted to bring with him monastic customs and traditions from Normandy, to the dismay of the Glastonbury community. ${ }^{52}$

Not all monasteries in England had such far-reaching rights as Bury and Glastonbury, and we should be wary of assuming that even these were always able to put into practice the full range of powers claimed in their archives. It is nevertheless quite clear that post-Conquest English monasteries did routinely claim some exemption from public systems of justice, at least to the same degree as other landlords. ${ }^{53}$ Naturally such a generalization hides a multitude of specificities. In many, perhaps most, cases, very serious crimes such as murder were reserved for royal justice, although even this was not always so. ${ }^{54}$ In no monastery, though, even those with the most ambitious claims, do we find any reference to advocates, let alone regulations of advocates' powers such as were produced in the Reich. Instead, virtually every English monastery of any size was expected to administer some justice on its lands through its own monastic officials, "almost, if not quite, as a matter of course." ${ }_{55}$ Often monks had difficulties with these officials, for power was difficult to delegate-but there was no dispute that they were in principle under the abbot's direct control and not external to the monastery in any meaningful sense.

In short, the administration of justice on monastic lands in post-Conquest England was a matter of negotiation between monasteries and their agents on the one hand, and the king and his agents on the other. This perhaps reflected the importance of justice for the Norman kings in ruling their unusually centralized kingdom, but it also says something about the nature and perception of these monastic communities-a point to which we shall return. ${ }^{56}$

\footnotetext{
${ }^{50}$ As emphasized by Julia C. Crick, "Pristina Libertas: Liberty and the Anglo-Saxons Revisited," Transactions of the Royal Historical Society 14 (2004): 47-72. Benjamin Thorpe's phrase (a footnote to his edition of Ine's charter) is cited by Naomi D. Hurnard, “The Anglo-Norman Franchises," English Historical Review 64 (1949): 289-323, at 323.

${ }^{51} \mathrm{John}$ Scott, The Early history of Glastonbury: An Edition, Translation, and Study of William of Malmesbury's “De antiquitate Glastonie ecclesie” (Woodbridge, UK, 1981), 154-56.

${ }^{52}$ On the "chant riot," see David Hiley, "Thurstan of Caen and Plainchant at Glastonbury: Musicological Reflections on the Norman Conquest," Proceedings of the British Academy 72 (1986): 57-90.

${ }_{53}$ An excellent overview is provided by John Hudson, Oxford History of the Laws of England, vol. 2, 871-1216 (Oxford, 2012), 56-62, 284-97. For further studies, see Shirley, Secular Jurisdiction; Martin Brett, "The English Abbeys, Their Tenants and the King (950-1150)," in Chiesa e mondo feudale nei secoli X-XII (Milan, 1995), 277-302; Mary Lobel, "Ecclesiastical Banleuca in England," in Oxford Essays in Medieval History Presented to Herbert Edward Salter (Oxford, 1934), 122-40; and W. L. Warren, The Governance of Norman and Angevin England (London, 1987), 206-11.

${ }^{54}$ See Johnson and Cronne, Regesta, xxii (with examples).

${ }^{55}$ Davis, Regesta, xxxii. See also Paul A. Brand, "The Rise and Fall of the Hereditary Steward in English Ecclesiastical Institutions, 1066-1300," in Warriors and Churchmen in the High Middle Ages: Essays Presented to Karl Leyser, ed. Timothy Reuter (London, 1992), 145-62.

${ }^{56}$ See also the comments about English monasticism in Alain Boureau, La loi du royaume: Les moines, le droit et la construction de la nation anglaise (XIe-XIIIe siècles) (Paris, 2004), esp. 23-38.
}

Speculum 92/2 (April 2017) 
Northern Italy

In northern Italy, unlike England but similarly to the Reich, references to people termed advocates (advocati) are common in monastic documents. These figures are, however, simply legal representatives, akin to those documented across the Frankish kingdoms in the Carolingian period. ${ }^{57}$ That does not mean Italian monasteries had no responsibility for justice. Quite on the contrary, monasteries in Italy were taking responsibility for the administration of justice even from before 900 in a way foreign to the rest of the Carolingian world, to judge from the livelli contracts that conferred rights to adjudicate certain kinds of disputes for their tenants. It is not clear whether we can talk of a distinctive "signoria ecclesiastica," but we can be sure that monasteries routinely exercised powers of justice from the eleventh century onwards. ${ }^{58}$

Exactly how things worked in practice is a little uncertain, since much of the evidence is either rather late or thinner than sometimes assumed. ${ }^{59}$ But the key point is that, in Italy as in England, there was no sense that monastic communities needed external figures to validate or to undertake normal judicial business. ${ }^{60}$ For example, the nuns of San Giulia of Brescia received a string of papal charters confirming that no one could hold a court on their lands without permission. ${ }^{61}$ There is no record in their archives that this ever became the object of any serious tension. They did have a prominent advocate, Lanfranc of Cazzago, but when we see him performing his role, it is in dutifully attending a ducal court in 1050 to assert the nuns' control over the jurisdiction of their properties. Lanfranc continued to provide valuable judicial assistance to the nuns in later years, too, for example in 1070 helping them carry out the leasing of a castle at Pian Camuno with all the

\footnotetext{
${ }^{57}$ This role is overwhelmingly the most popular context for advocates' frequent appearance in Cesare Manaresi, ed., I placiti del "Regnum Italiae," 3 vols. (Rome, 1955-60). Important recent studies: François Menant, Campagnes lombardes du Moyen Âge: L'économie et la société rurales dans la région de Bergame, de Crémone et de Brescia du Xe au XIIIe siècle (Rome, 1993), 431-32, 706-13; François Bougard, La justice dans le royaume d'Italie de la fin du VIIIe siècle au début du XIe siècle, Bibliothèque des Écoles françaises d'Athènes et de Rome 291 (Rome, 1995), 264-69. Giuseppe Albertoni has a study in hand of advocates in Italy in this period.

${ }^{58}$ Cinzio Violante, "La signoria rurale nel secolo X: Proposte tipologiche," in Il secolo di ferro, Settimane di Studio del Centro Italiano di Studi sull'Alto Medioevo 38 (Spoleto, 1991), 329-85, doubted that a specifically ecclesiastical seigneurie existed, while Giancarlo Andenna, "La signoria ecclesiastica nell'Italia settentrionale," in Chiesa e mondo feudale nei secoli X-XII, Miscellanea del Centro di Studi Medievali 14 (Milan, 1995), 111-49, noted that the "signoria territoriale di banno ecclesiastica" was essentially the same as that exercised by laymen. See Laurent Feller, Paysans et seigneurs au Moyen Âge: VIIIe-XVe siècles (Paris, 2007), 120-25, for contextualized discussion.

${ }_{59}$ The monastery of Farfa, near Rome, is often cited as having taken control of the administration of justice around 1000: Chris Wickham, Medieval Rome: Stability and Crisis of a City, 900-1150 (New York, 2014), 42-52; and Pierre Toubert, Les structures du Latium médiéval: Le Latium méridional et la Sabine du IXe siècle à la fin du XIIe siècle (Paris, 1973), 1284-87, 1305-13. For judicial touring by the nuns of San Brescia in the late twelfth century, see Menant, Campagnes, 431 with n. 121, and 432 n. 125 .

${ }^{60}$ Gregorio Penco, Storia del monachesimo in Italia: Dalle origini alla fine del medio evo (Rome, 1961), 369-70, 378-79; Bougard, Justice, 267-69.

${ }^{61}$ Ezio Barbieri, Irene Rapisarda, and Gianmarco Cossandi, eds., Le carte del monastero di S. Giulia di Brescia I (759-1170), Codice Diplomatico della Lombardia Medievale (CDLM) (online publication at http://cdlm.unipv.it/): for example, a charter of Pope Innocent II (1132), vol. 1, no. 117.
}

Speculum 92/2 (April 2017) 
judicial rights held by the convent. ${ }^{62}$ Lanfranc's role seems to have been very clearly perceived as using his expertise to mediate between the monastery and external authorities. When the nuns were obliged to negotiate disputes over the revenues from their holdings, these disputes were with the inhabitants, not their advocates. ${ }^{63}$

The monastery of Sant'Ambrogio of Milan, an old Benedictine establishment, presents a similar picture. ${ }^{64}$ Here too the monastic archives preserve plenty of reference to advocates in the sense of legal representatives, who were often prominent citizens. We see one, for example, validating the oaths taken by the inhabitants of the village of Arogno when they pledged not to challenge the claims of Sant'Ambrogio's cell, San Zeno, over nearby lands. ${ }^{65}$ Yet the abbot was nevertheless very much capable of representing himself as the sole source of legal authority for the monastery's estates. For instance, in a charter supposedly issued by the monastery in 1015 , the inhabitants of an apparently precociously self-conscious rural community at Inzago committed themselves to the jurisdiction of the abbot, "as if to the count." ${ }^{66}$ This text may have been interpolated, but if so this must have been done before the extant copy was written in the middle of the twelfth century.

Like his counterparts at Bury Saint Edmunds and Glastonbury, the abbot of Sant'Ambrogio was intent on defending these rights. For instance, in the later twelfth century the monastic community vigorously contested the claims of the bishop of Como to exercise justice over estates in Valtellina and even produced a questionnaire for local inhabitants exploring how these rights had been exercised, which survives as a scruffy original in the Archivio di Stato of Milan. Had this bishop's agent ever extorted mendantiae; and if so, when, where, from whom, for how much, and what for-and what had he looked like? ${ }^{67}$ The text gives an excellent indication of what kind of rights the monastery was claiming, without a whisper of an advocate's involvement.

\footnotetext{
${ }^{62}$ Barbieri, Rapisarda, and Cossandi, Le carte del monastero di S. Giulia, no. 75 and no. 84; also Manaresi, I placiti, vol. 1, no. 384.

${ }^{63}$ E.g., Barbieri, Rapisarda, and Cossandi, Le carte del monastero di S. Giulia, no. 149.

${ }^{64}$ On the monastery's early history, see Ross Balzaretti, The Lands of Saint Ambrose: Monks and Society in Early Medieval Milan (Turnhout, forthcoming).

${ }^{65}$ Cesare Manaresi and Giovanni Vitanni, eds., Gli atti privati milanesi e comaschi del secolo XI, 4 vols. (Milan, 1933-69), vol. 1, nos. 40, 97-98 (1010). For an example of a prominent family from Milan, the Grassi, who were hereditary advocates of Sant'Ambrogio, see Chris Wickham, Sleepwalking into a New World: The Emergence of Italian City Communes in the Twelfth Century, Lawrence Stone Lectures (Princeton, 2015), 219 n. 31.

${ }^{66}$ Manaresi and Vitanni, Gli Atti, vol. 3, no. 75 (175). The charter shows "signoria territoriale con piena giurisizione del signore," according to Violante, "Signoria rurale," 373. On the earlier history of Inzago, see Ross Balzaretti, "The Politics of Property in Ninth-Century Milan: Familial Motives and Monastic Strategies in the Village of Inzago," Mélanges de l'École française de Rome, Moyen Âge 111 (1999): 747-70; the tension with the inhabitants continued into the later twelfth century, when Emperor Frederick II confirmed the monastery's possession. Another example of the monastery's territorial power is explored in Rosario Romeo, "La signoria dell'abate di Sant'Ambrogio di Milano sul comune rurale di Origgio nel secolo XIII," Rivista storica italiana 69 (1957): 340-77, 473-507.

${ }^{67}$ Ada Grossi and Marta Mangini, eds., Le carte del monastero di S. Ambrogio di Milano, III, 1101-1200, 2 vols., Codice diplomatico della Lombardia medievale (online publication at http:// cdlm.unipv.it/), vol. 2, no. 42 (1187). The original is preserved in Milan, Archivio di Stato, MS Pergamene Cartella 313, and I am grateful to the archives for allowing me access to this remarkable document.
}

Speculum 92/2 (April 2017) 
Naturally monasteries like Sant'Ambrogio could and did enter into agreements with powerful people to provide protection: for instance, the monks made an agreement in 1105 with Alberic the vicedominus of Como to protect their interests. ${ }^{68}$ That kind of protection was normal across the whole of the Latin West, as one would expect in circumstances where local powerbrokers were a more immediate presence than distant kings. But even with the extraordinarily rich Italian documentation to draw upon (there are over nine hundred charters extant from Milan alone in the eleventh century), there are no Italian texts comparable to the advocacy charters of the Reich. This may reflect in part the relative unprofitability of justice in northern Italy when compared with lands to the north, and perhaps in part too the alternative possibilities for power building afforded by rapidly growing urban communities. ${ }^{69}$ But it may also be simply that northern Italian monastic communities felt no need for advocates in this capacity. The only exception is to be found in Gorizia (or Görz) in the far northwest, near Aquileia in Friuli. Here, monastic advocacy provided a, or perhaps the, basis of power for a family who became the counts of Gorizia, as can be traced in a series of charters that began in 1138 and culminated in $1202 .^{70}$ These texts emphasized that the power of the advocate rested ultimately on his control of the placita of monasteries. Gorizia apart, there was in Italy no monastic advocacy of the German typeand Gorizia is so far to the north that in a sense it only confirms the general point.

\section{Monasteries and the Administration of Justice outside the Reich, 2: FRANCE}

In neither England nor Italy, then, is there much evidence for anything like the advocacy attested by the charters from Saint-Mihiel or Reichenau, with the exception of the far northwest of Italy on the linguistic and political border. It has long been recognized that the case of France is more complicated, despite occasional attempts to mold the evidence to fit a German historiographical framework. ${ }^{71}$ One of the earliest approaches to this complexity was that pioneered by the legal historian of Lorraine, Félix Senn, who in 1903 suggested that a line ran from Lyons, through Bourges, Orléans, and Chartres, into Normandy, a line to whose south and west monastic advocacy was not to be found. ${ }^{72}$ This "Senn line"

\footnotetext{
${ }^{68}$ Grossi and Mangini, Le carte del monastero di S. Ambrogio di Milano, vol. 1, no. 7.

${ }^{69}$ On profitability, see Feller, Paysans, 157-58. On towns, see now Wickham, Sleepwalking.

${ }^{70}$ As already pointed out by Mayer, Fürsten, 18 n. 3. Detailed study is provided by Elsa Sgubin, "Avvocazia dei conti di Gorizia nel patriarcato d'Aquileia," Studigoriziani 33 (1963):96-154; see also Wilhelm Baum, Grafen von Görz in der europäischen Politik des Mittelalters (Klagenfurt, 2000), and Reinhard Härtel, "Görz und die Görzer im Hochmittelalter," Mitteilungen des Instituts für Österreichische Geschichtsforschung 110 (2002):1-66. The charters are calendared by Hermann Wiesflecker, Regesten der Grafen von Görz und Tirol, Pfalzgrafen von Kärnten, vol. 1, 957-1271 (Innsbruck, 1949), e.g., no. 319 (87).

${ }^{71}$ Ernst Sackur, Die Cluniacenser in ihrer kirchlichen und allgemeingeschichtlichen Wirksamkeit bis zur Mitte des elften Jahrhunderts, 2 vols. (Halle, 1892-94), vol. 2, 416-18.

${ }^{72}$ The absence of monastic advocacy in Normandy is the subject of a celebrated article by Jean Yver, "Autour de l'absence d'avouerie en Normandie: Notes sur le double thème du développement du pouvoir ducal et de l'application de la réforme grégorienne en Normandie," Bulletin de la Société
}

Speculum 92/2 (April 2017) 
has subsequently proven influential, and rightly so, for it does indeed reflect the evidence. $^{73}$

\section{South and West}

To the west and south of Senn's line, there is no more sign of monastic advocacy than there was in post-Conquest England (which is unlikely to be a coincidence, given the circumstances of the Conquest). This is not to say that there were not approximations. Take, for example, the case of Saint-Aubin in Angers. In the eleventh century, this relatively conservative monastery remained close to the count of Anjou and overtly hostile to some aspects of church reform, as the monks spectacularly demonstrated when they refused to allow Pope Urban II to consecrate their church in $1096 .{ }^{74}$ A little earlier, the monks had produced a record of the attempt by a local castellan of Montreuil-Bellay to assert his authority over the monks' estate at Méron, some sixty kilometers away from Angers, in texts that recall some of the aspects of advocacy encountered in the pages above.

In a now famous pair of charters, the monks made it clear that the castellan Rainald and his representatives had overstepped the mark by beating and even killing monastic dependants. ${ }^{75}$ Still, the monks accepted that Rainald did have legitimate authority in six areas: rape, arson, bloodshed, and theft, as well as hare hunting and road tolls, though they maintained that even in these cases, the monks should have the chance to deal with the matter first (a clause noticeably absent from Rainald's version of the text). ${ }^{76}$ What is more, we know from another charter that the monks had given Rainald land in exchange for his promise to protect monastic estates. Justice and protection: precisely the two themes that Hermann of Niederaltaich had emphasized in his account of advocacy.

Yet the monks at Saint-Aubin did not call Rainald an advocate (advocatia had quite a different meaning in Anjou) — and for good reason since, on closer inspec-

des Antiquaires de Normandie 57 (1963-64): 189-283. For a critique, see Sally Vaughn, The Abbey of Bec and the Anglo-Norman State 1034-1136 (Woodbridge, UK, 1981), 32.

${ }^{73}$ Félix Senn, L'institution des avoueries écclesiastiques en France (Paris, 1903), 104. For citations, see Thomas Kohl, Konflikt und Wandel um 1100-Deutschland und Frankreich im Zeitalter von Investiturstreit und Société féodale (Tübingen, forthcoming). See also Mayer, Fürsten, 19.

${ }^{74}$ Olivier Guillot, Le comte d'Anjou et son entourage au 11e siècle, 2 vols. (Paris, 1972), provides the classic discussion of the counts; more recently, Kohl, Konflikt und Wandel.

${ }^{75}$ Bertrand de Broussillon, ed., Cartulaire de l'abbaye de Saint-Aubin d'Angers, 3 vols. (Angers, 1903), vol. 1, nos. 220-21 (256-61), taken from the late eleventh-century cartulary, Angers, Bibliothèque municipale, MS 829 (now available online through the website of the Bibliothèque municipale of Angers at http://bm.angers.fr/patrimoine-depot-legal/collections-numerisees/manuscrits-de-l-abbaye -saint-aubin/index.html), fols. 72v-74v. The Méron dossier is discussed by Henk Teunis, The Appeal to Original Status: Social Justice in Anjou in the Eleventh Century (Hilversum, 2006), 79-81; Bruno Lemesle, Conflits et justice au Moyen Âge: Normes, loi et résolution des conflits en Anjou aux XIe et XIIe siècles (Paris, 2008), 123-36; Bisson, Crisis, 139-42; and Richard E. Barton, Lordship in the County of Maine, c. 890-1160 (Woodbridge, UK, 2004), 142. There is also useful discussion in Kathryn Dutton, "Geoffrey, Count of Anjou and Duke of Normandy, 1129-51" (PhD diss., University of Glasgow, 2011).

76 "Antiqua consuetudo fuit quod si aliquis se clamavit de homine Sancti Albini ad vicarium de Mosteriolo, vicarius non distrinxit eum donec aut monachus aut qui Maironum servabat rectum clamanti vetuisset”: Broussillon, Cartulaire, vol. 1, no. 220 (256).

Speculum 92/2 (April 2017) 
tion, the conditions at Méron turn out to be quite different from advocatial relations in the east. ${ }^{77}$ The six "cases" (forsfacta) reserved to Rainald were defined more by ideas of public justice than by monastic anxieties: these were rights that the Angevin counts attempted to monopolize as "high justice," as is evident from earlier charters to the monastery. ${ }^{78}$ And the monks soon changed their position even on this, as the community belatedly embraced "reform" in the years around $1100 .^{79}$ In a 1129 charter, they declared that their lands at Méron had originally been "in every respect extremely free"(omnino liberrime) before they had voluntarily (sua sponte) placed comital vicarii there, whose powers the count had subsequently delegated to Montreuil; the claim was echoed in a narrative from around 1151, in which the monks asserted that they had owned Méron long before the counts had imposed their authority in the area by building the castle at Montreuil. ${ }^{80}$ In other words, the Saint-Aubin monks in 1129 confirmed that the secular exercise of power at Méron was based on public, delegated authority, but simultaneously undermined that delegation by invoking an older, precomital past when the monks' authority had been unfettered.

The monks of La Trinité at Vendôme seem to have had fewer hesitations in asserting their exemption from external secular jurisdiction. A charter dated to 1040 declared that the monastery should have its own court, the curia abbatis. In fact the text in question is probably a forgery from 1100, as are a few other similar ones. ${ }^{81}$ But whatever the document's date, what is striking is that it made no reference at all to any external agent having legitimate claim over judicial business within the monastery. The monks considered this something that they could deal with themselves, and we can see that at least sometimes they put this idea into action, at least in the late eleventh century. ${ }^{82}$ Laymen certainly did try to extract revenues from La Trinités lands, sometimes on the basis of claims of justice. At no point, though, did the monks at Vendôme accept that such claims held any legitimacy: as one specialist has recently commented, their aim in the decades around 1100 was to be "free of all secular influence." 83 There was no monastic advocacy here. ${ }^{84}$

\footnotetext{
${ }^{77}$ Dominique Barthélemy, "Une crise de l'écrit? Observations sur des actes de Saint-Aubin d'Angers (XIe siècle)," Bibliothèque de l'École des Chartes 155 (1997): 111-13, for "l'avouerie angevine."

${ }^{78}$ For example, Geoffrey Greymantle's important charter of 966 , which granted vicaria potestas but kept back theft, murder, and arson: Broussillon, Cartulaire, vol. 1, no. 2 (6).

${ }^{79}$ On this, see Guillot, Comte d'Anjou; and Kohl, Konflikt und Wandel.

${ }^{80}$ Broussillon, Cartulaire, vol. 2, no. 932 (408); the chronicle is in Paul Marchegay and Émile Mabille, ed., Chroniques des églises d'Anjou (Paris, 1869), 83-90, at 85 (for a discussion of the source, see Dutton, "Geoffrey," e.g., appendix I, 4).

${ }^{81}$ Charles Métais, ed., Cartulaire de l'abbaye de la Trinité de Vendôme, 5 vols. (Paris, 1893-1904), vol. 1, no. 37. For commentary, see Kohl, Konflikt und Wandel, drawing on Hermann Meinert, "Die Fälschungen Gottfrieds von Vendôme," Archiv für Urkundenforschung 10 (1928): 232-326.

${ }^{82}$ Meinert, "Fälschungen," 241, referring to charter no. 319 from the 1080s.

${ }^{83}$ Jean-Hervé Foulon, Église et réforme au Moyen Âge: Papauté, milieux réformateurs et ecclésiologie dans les Pays de la Loire au tournant des XIe-XIIe siècles (Brussels, 2008), 286: "libre de toute influence séculière.”

${ }^{84}$ As already emphasized by Meinert, "Fälschungen," 271: "Von einer Vogtei in dem Sinne, wie bei den süddeutschen Klöstern üblich war, lässt sich hier wohl nicht reden.”
}

Speculum 92/2 (April 2017) 


\section{North and East}

To the north and the east of Senn's line, however, matters were less clear-cut. Flanders was part of the kingdom of West Francia, but it is well known that advocacy was important there, even if the topic still "awaits its historian," as one recent article put it. ${ }^{85}$ Like some Picardy communities (such as Corbie or SaintRiquier), Flemish monasteries produced charters regulating advocacy in ways that would have been absolutely familiar to monastic houses east of the Meuse or Scheldt. ${ }^{86}$ A particularly interesting case is provided by a charter in favor of Saint-Bertin, issued it seems in 1042 by Count Baldwin V of Flanders. ${ }^{87}$ In some respects this is a typical advocacy charter, though a little earlier than most, for which reason it has often been treated with caution. Authentic or not, what is especially interesting is how the text was "activated" in the decade that followed 1100 , under Abbot Lambert. This activation took place in the monastery of SaintBertin itself, but, much as charters and expertise from St. Maximin of Trier and Reichenau were put at the service of neighboring monasteries at around this time, in this instance too there was also a "circulation d'actes," as Jean-Francois Nieus and Steven Vanderputten have shown. ${ }^{88}$ The Saint-Bertin text was brought out to serve as a template first for the monastery of Saint-Amand, who used it to create a charter in 1116, and then for the recently refounded institution at Marchiennes, whose community relied on it to create a splendid forgery dated to 1038, backed up with a concentration on advocates in its miracle stories. ${ }^{89}$

Further south, however, things were more ambiguous. For example, the monastery of Saint-Denis in Paris began dealing with justice itself, directly, from an early date, as confirmed in a charter from King Robert the Pious from 1008, linked to forged charters produced by the monks in the name of King Dagobert

\footnotetext{
${ }^{85}$ See Jean-Francois Nieus and Steven Vanderputten, "Diplôme princier, matrice de faux, acte modèle: Le règlement d'avouerie du comte Baudoin V pour Saint-Bertin (1042) et ses réappropriations sous l'abbatiat réformateur de Lambert (1095-1123)," Medieval Low Countries 1 (2014):1-59.

${ }^{86} \mathrm{~A}$ useful though dated overview is provided by Charles Pergameni, L'avouerie écclesiastique belge des origines a la période bourguignonne (Gana, 1907), including a lengthy appendix listing all the advocacy regulation texts known to the author.

${ }^{87}$ On Saint-Bertin's advocates, see also Elisabeth van Houts and Rosalind Love, eds. and trans., The Hyde (Warenne) Chronicle (Oxford, 2013), liv-lv and 107-12 (with further references). The circumstances of Baldwin V's charter are assessed in detail, on the presumption of its authenticity, in Steven Vanderputten, "Monks, Knights, and the Enactment of Competing Social Realities in Eleventh- and Early-Twelfth-Century Flanders," Speculum 84/3 (2009): 582-612.

${ }^{88}$ Nieus and Vanderputten, "Diplôme princier," including an edition of the text in its various forms.

${ }^{89}$ The Saint-Amand charter is edited in Fernand Vercauteren, ed., Actes des comtes de Flandres 1071-1128 (Brussels, 1938), no. 80 (178-80); see in general Henri Platelle, La justice seigneuriale de l'abbaye de Saint-Amand: Son organisation judiciaire, sa procédure et sa compétence du XIe au XVIe siècle (Louvain, 1965). The forged Marchiennes charter is most easily accessed through the online Artem database at http://www.cn-telma.fr/originaux, no. 368; it was confirmed by Count Charles the Good in 1125: Vercauteren, Actes, no. 118 (269-71). For the miracles, see Henri Platelle, "Crime et châtiment à Marchiennes: Étude sur la conception et le fonctionnement de la justice d'après les Miracles de Sainte Rictrude (XIIe s.)," Sacris erudiri 24 (1980): 155-202. For the wider context, see Steven Vanderputten, "Fulcard's Pigsty: Cluniac Reformers, Dispute Settlement and the Lower Aristocracy in Early Twelfth-Century Flanders," Viator 38/1 (2007): 91-115.
}

Speculum 92/2 (April 2017) 
and King Charles the Bald. ${ }^{90}$ True, in the course of the twelfth century the monastery had occasional brushes with people who claimed to be advocates. But it is striking that when these claims were made, the monastery either bought them off (as Abbot Suger did at Toury) or treated them as entirely illegitimate. ${ }^{91}$ For the most part, the exactions levied by laymen on the monastery's estates were treated as "exactions" and unjust "customs." 92 At the nearby monastery of SaintMaur-des-Fossés, the eleventh-century monks acknowledged the claims of men claiming to be advocates in their charters, but at the same time used hagiographythe Vita Burchardi - to erase any traces of advocacy from the community's past. ${ }^{93}$

Monasteries further to the east demonstrated a similar ambivalence about advocacy. For instance, the monks at Saint-Remi of Reims did sometimes talk of laymen as exercising the rights of advocacy, but only seldom issued full-blown charters of regulation. ${ }^{94}$ But the monastery also had lands east of the Meuse, and for these there was no hesitation at all in talking about advocacy. In a fascinating document from 1149, Emperor Konrad III declared that only the advocate who had received the bannum from his own hands (the Bannleibe, as mentioned above) could hold placita or settle cases in Saint-Remi's lands in the Reich at Kusel. ${ }^{95}$ It may be significant that the monks of Saint-Remi had not themselves drafted the terms of this charter, which was instead the work of Wibald of Stavelot, an abbot

${ }^{90}$ William M. Newman, Catalogue des actes de Robert II roi de France (Paris, 1937), no. 31 (3942); the text is also available on the Artem website, nos. 3052-53 (two redactions). On the forgeries perhaps made to elicit Robert's charter, see Theo Kölzer, ed., Die Urkunden der Merowinger, 2 vols., MGH DD Mer. 1 (Hannover, 2001), nos. 29 (78-81) and 44 (115-16); and Arthur Giry, Maurice Prou, and Georges Tessier, eds., Recueil des Actes de Charles II le Chauve, roi de France, 3 vols., Chartes et Diplômes Relatifs à l'Histoire de France 8 (Paris, 1943-52), vol. 2, no. 479 (59397). General context is provided by Rolf Grosse, Saint-Denis zwischen Adel und König: Die Zeit vor Suger (1053-1122) (Stuttgart, 2002); and Patrick J. Geary, Phantoms of Remembrance: Memory and Oblivion at the End of the First Millennium (Princeton, 1994), 107-14.

${ }^{91}$ For Toury, see Suger, "De administratione," in Suger, Oeuvres, ed. Françoise Gasparri, 2 vols. (Paris, 1996-2001), 1:86-88 (written around 1144). Compare with agreements involving advocacy at Laversine c. 1128 and Cergy c. 1144, registered in Suger, Oeuvres, 2:281 and 285.

${ }^{92}$ For example, the exactiones of the count of Dammartin at Tremblay and the oppressio of the lord of Méréville at Monnerville: Suger, "De administratione," 60-62 and 78-80.

${ }^{93}$ Charters: Jacques Boussard, ed., “Actes royaux et pontificaux des Xe et XIe siècles, du chartrier de Saint-Maur des Fossés," Journal des savants (1972): 81-113. Hagiography: Odo of Saint-Maur, Vie de Bouchard le Vénérable, comte de Vendôme, de Corbeil, de Melun et de Paris (Xe et XIe siècles), ed. and trans. Charles-Marie Bourel de la Roncière, (Paris, 1892). For commentary, see Michel Lauwers, "La 'vie du seigneur Bouchard, comte vénérable': Conflits d'avouerie, traditions carolingiennes et modèles de sainteté à l'abbaye des Fossés au XIe siècle," in Guerriers et moines: Conversion et sainteté aristocratiques, ed. Lauwers (Antibes, 2002), 371-418.

${ }^{94}$ For advocacy in the region, see Michel Bur, La formation du comté de Champagne, v. 977v. 1150 (Nancy, 1977), 343-92. An example of a charter issued by Saint-Remi dealing with advocacy is one issued in 1126 concerning Alliancelles, preserved in Archives départementales de la Marne, Annexe Reims, $56 \mathrm{H}$ 102. I am grateful to the archivists for permitting access to this charter.

${ }^{95}$ Friedrich Hausmann, ed., Die Urkunden Konrads III und seines Sohnes Heinrich, MGH DD K III (Vienna, 1969), no. 210 (377-79), the only known placitum charter of Konrad. See Clauss, Untervogtei, 7-8. On the history of the monastery's estate there, see Edward Roberts, "Hegemony, Rebellion and History: Flodoard's Historia Remensis ecclesiae in Ottonian Perspective," Lournal of Medieval History 42 (2016): 155-76.

Speculum 92/2 (April 2017) 
of a monastery in the Reich with a great deal of personal interest in and experience of monastic advocates. ${ }^{96}$

Other monastic communities in this part of the French kingdom had similarly fluid attitudes to advocacy. For example, the monastery of Saint-Urbain in the diocese of Châlons-sur-Marne, founded by the king and bishop in the ninth century, made in 1132 a charter that is, squarely, an advocacy regulation similar to those of Reichenau or Saint-Mihiel. ${ }^{97}$ This charter of regulation, now preserved in Paris and still lacking a printed edition, did not however settle the matter. According to a series of unimposing (and unpublished) charters now preserved in the departmental archives in Chaumont, one aristocratic family maintained judicial rights at the monastery's estate at Landéville until the 1190s, when the monastery finally won them back..$^{98}$ More broadly, the monastery continued to accept the claims of the Joinville family to act as its general advocate. ${ }^{99}$ By the thirteenth century, these claims had been reconceived as merely political protection or patronage, labeled as garde; and in 1266 the monastery suggested to the king that even this really belonged to him, much to Jean of Joinville's irritation. ${ }^{100}$ Not until the fourteenth century, however, after a little judicious charter burning and a large payment in silver, was the issue finally resolved, and the garde formally transferred to the king.

\section{The Geography of Monastic Advocacy, 1: Political Approaches}

It should by now be evident that the judicial tasks allotted to monastic advocates within the Reich and along its western fringes in the decades around 1100 were performed outside it primarily by the monks themselves, together with their subordinated officials, in conjunction or in competition with public officials. As a result, monastic advocacy of the kind that was normal and so important in the Reich was essentially absent in England, northern Italy, and most of France. This

\footnotetext{
${ }^{96}$ For Wibald's interest, see Martina Hartmann, ed., Das Briefbuch Abts Wibalds von Stablo und Corvey, 2 vols., MGH Briefe d. dt. Kaiserzeit 9 (Hannover, 2012), vol. 2, no. 270 (578), "tyrannidem advocatorum," in reference to Waulsort; see also no. 289 (612) and no. 359 (755). See Franz-Josef Jakobi, Wibald von Stablo und Corvey (1098-1158): Benediktinischer Abt in der frühen Stauferzeit (Münster, 1979), 216-25. On Wibald and Stavelot's advocates, see now Nicolas Schroeder, Les hommes et la terre de Saint Remacle: Histoire sociale et économique de l'abbaye de Stavelot-Malmedy, VIIe-XIVe siècles (Brussels, 2015).

${ }^{97}$ Paris, Bibliothèque nationale de France, MS Collection de Moreau 55, fols. 139-40; HenriFrançois Delaborde, Jean de Joinville et les seigneurs de Joinville: Suivi d'un catalogue de leurs actes (Paris, 1894), no. 24.

${ }_{98}$ Archives départmentales de la Haute-Marne, 9 H 19; Delaborde, Joinville, nos. 84, 90, and 140. I am grateful to the Archives départmentales for granting access to these documents.

${ }^{99}$ A recent discussion that brings out the importance of monastic advocacy for the family is provided by Jean-Noël Mathieu, "Nouvelles recherches concernant le lignage de Joinville," Les cahiers haut-marnais 190 (1992): 1-25.

${ }^{100}$ Jean de Joinville, Vie de Saint Jean, ed. and trans. Jacques Monfrin (Paris, 2010), chap. 677 (338): according to Jean, the king suggested that "il peut bien estre que l'eritage est vostre, mez en la garde de vostre abbaïe n'avés vous riens," but Jean was able to convince him otherwise. The edition has a useful summary of the affair at xxi-xxiii. On garde, see Noël Didier, La garde des églises an XIIIe siècle (Paris, 1927).
}

Speculum 92/2 (April 2017) 
pattern is clear, and until we can account for it, we may doubt whether we have really understood monastic advocacy at all.

Most historians who have looked at monastic advocacy have, unsurprisingly in view of this evidence, done so from within a German-language perspective, shaped by the tradition of "regional history," or Landesgeschichte, that consistently emphasized the specific. As a result, they have seldom considered why monasteries elsewhere in the Latin West managed without it. A comparative perspective does not seem urgent when every region, indeed every monastery, is considered a Sonderfall, or "special case," and where the emphasis is on Mannigfaltigkeit ("multiplicity"); nor is it easy to carry out comparisons on the basis of research conducted in this vein. ${ }^{101}$

More profoundly, though, the way in which German-language research into advocacy has traditionally been framed has further hampered comparative work. Within this framework, advocacy has been treated as essentially a product of the Germanic nature of aristocrats' power: Munt, the power to protect that was autogenous to the aristocracy (Adel); and Eigenkirchenwesen, the propensity to own churches, for which advocacy represented a compromise responding to reform. ${ }^{102}$ If advocacy was determined by the structure of the Germanic "state" or constitution in this way, then it is obvious why advocacy should have been restricted to the Reich, and the matter seems not to require further exploration. ${ }^{103}$ Yet to modern eyes, such an ethnicized approach, reliant on concepts that are increasingly drawing fire in the most recent scholarship, seems unlikely to offer an adequate explanation. After all, monastic advocacy was certainly prevalent in the empire, but, as we have seen, it could also be found in non-German-speaking areas and outside the borders of the Reich, shading off west of the Meuse in Flanders and Burgundy, while it was entirely absent in "Germanic" Anglo-Saxon England and post-Lombard Italy too.

Recent English-language work has taken what seems at first sight a very different approach. In a recent book by Thomas Bisson, the advocacy found in the Reich is merely a regional variant of the "bad lordship" that characterized the whole of the Latin West in the twelfth century. Yet although Bisson's approach is located within the predominantly francophone literature about the "mutation féodale," such an equating of the experiences at Méron and Condé-sur-Meuse can also be seen as the application of an originally German-language concept

\footnotetext{
${ }^{101}$ E.g., Hans Patze, Die Entstehung der Landesherrschaft in Thüringen (Cologne, 1962), 380-404. On Mannigfaltigkeit, see Mayer, Fürsten, xv and 313.

${ }^{102}$ On Munt, see Adolf Waas, Vogtei und Bede in der deutschen Kaiserzeit (Berlin, 1919-23). On the topic of Eigenkirchenrecht, see now Susan Wood, The Proprietarv Church in the Medieval West (Oxford, 2006).

${ }^{103}$ Karl Bosl, "Die Vogtei: Ihre innere Entwicklung im Mittelalter," in Handbuch der deutschen Geschichte I: Frühzeit und Mittelalter, ed. Bruno Gebhardt, 8th ed. (Stuttgart, 1954), 622-25. On the importance of the "Struktur des Staates" in shaping advocacy, see Mayer, Fürsten, 18 and 19, arguing that advocacy can only be understood "vom Staat aus." This approach seems to have influenced the important discussion of advocacy in Giles Constable, The Reformation of the Twelfth Century (Cambridge, MA, 1996), 249-56.
}

Speculum 92/2 (April 2017) 
of medieval lordship to a wider canvas. ${ }^{104}$ Justified though this may be in broad terms, it is surely important that the claims made by Rainald and Guido met with different responses: inserted into a discourse about public power or otherwise rejected by the monks at Méron, qualified but largely accepted by the monks at Condé. For the inhabitants of these villages, this might not have made a great deal of difference, but at a higher scale, as we have seen, monastic advocacy like that at Condé buttressed configurations of power in the east in ways that were not possible in the west, and this also mattered. ${ }^{105}$

That historians working in French traditions have tended to pay more attention to regional diversity is natural in light of the evidence assessed above. Explanations for the presence and absence of advocacy have tended here to focus not on the nature of the aristocracy as such, but on politics: where political conditions were unstable, monasteries turned to advocates; as French kings began to assert themselves, advocacy melted away. ${ }^{106}$ In a stimulating and important recent analysis comparing Anjou and Swabia, Thomas Kohl has refined this approach, suggesting a connection with the survival or otherwise of the early medieval monastic immunity, whose importance in the earlier period is currently being revisited. ${ }^{107}$ Clearly monastic advocacy had some connection to monastic immunity, which was intended to insulate monasteries from secular pressures. Yet as Kohl himself notes, this merely transfers the problem: for why did immunity break down in one region and not in another?

In all these approaches, monastic advocacy tends to become a cipher for aristocratic power in one way or another, with the consequence that the monastic dimension is subordinated to the political and the legal. Given that the evidence, as we have seen, suggests advocacy in the Reich was shaped by the monks as much as by the aristocrats, it might be time to credit these socially and ideologically powerful communities with more capacity of action. ${ }^{108}$ If we use the charters dealing with advocates less as evidence for aristocratic practices of domination and territory building, and more as indications for how monasteries interacted with these aristocrats, then a new perspective opens up. Rather than considering monastic advocacy as merely reflecting the nature of the Germanic aristocracy or political circumstances, we might see it instead, or as well, as expressing something of the nature of monasticism in these regions: specifically, a profound anxi-

\footnotetext{
${ }^{104}$ Such comparison was already hinted at by Timothy Reuter, "Form of Lordship in German Historiography," in Pour une anthropologie du prélèvement seigneurial dans les campagnes médiévales (XIe-XIVe siècles), ed. Monique Bourin and Pascual Martínez Sopena (Paris, 2004), 51-61. For a cautious critique of the paradigm of lordship, at least for the early Middle Ages, see Charles West, "Lordship in Ninth-Century Francia: The Case of Bishop Hincmar of Laon and His Followers," Past and Present 226 (2015): 3-40.

${ }^{105}$ See note 145 below.

${ }^{106}$ Senn, L'institution des avoueries, 179-90; see also Didier, La garde des églises, 25-28; and Bur, Champagne, esp. 343-92.

${ }^{107}$ Kohl, Konflikt und Wandel. On the immunity, see now Steffen Patzold, "Benedictus Levita I, 279-eine echtes Capitulum von 829? Vorarbeiten zur Neuedition der Kapitularien Ludwigs der Frommen," Deutsches Archiv für Erforschung des Mittelalters 70 (2014): 67-86. See also note 40 above.

${ }^{108}$ For monks as “idéologues," see Dominique Iogna-Prat, Études clunisiennes (Paris, 2002), 9. For consideration of the social position of monasticism, see also Steven Vanderputten and Brigitte Meijns, eds., Ecclesia in medio nationis: Reflections on the Study of Monasticism in the Central Middle Ages (Louvain, 2011); and note 129 below.
}

Speculum 92/2 (April 2017) 
ety about monks carrying out, whether in person or through direct delegation, the full range of secular justice.

\section{The Geography of Monastic Advocacy, 2: A Monastic Approach}

That such anxiety existed would hardly in itself be surprising. Since late antiquity, judicial administration had been strongly associated with the kind of worldly business (negotia saecularia) that clerics were supposed to avoid, and from which monks were supposed to be fleeing. The notion that clerics and monks ought not to act as judges themselves was occasionally articulated in the ninth century. ${ }^{109}$ In the eleventh and twelfth centuries, however, it seems to have become more strongly and consistently expressed by a range of writers in the Reich.

For instance, the prolific author Gerhoch of Reichersberg, working in the diocese of Salzburg in the mid-twelfth century, insisted over and over again in the course of a long career and across a number of different texts that those in the church ought to have no involvement in the shedding of blood. For Gerhoch, that meant that the enactment of violent punishment, the Blutgericht, was properly reserved to kings and those wielding powers delegated by them: as he wrote in 1156, "The judgement and affairs of blood are absolutely prohibited to priests and others who serve God." 110 If clerics were to have duties of this nature placed upon them, then they should carry them out "through laymen obligated in fidelity to their churches." Gerhoch emphasized, however, that this power to judge ultimately came from the civil authorities, not from the church itself: not so much because these were public rights, but because they were at odds with the church's mission and nature. ${ }^{111}$

Gerhoch was of course a regular canon, but similar sentiments had already been expressed by Benedictine monks in literature produced a little earlier in the decades around 1100 in the course of debates over the so-called investiture controversy, for instance in the famous Liber de unitate ecclesiae conservanda, a text written at the Saxon monastery of Hersfeld in the 1090s. ${ }^{112}$ The Lotharingian author Sigebert of Gembloux also emphasized that clerics and monks should not wield the earthly sword in his famous letter to Pope Paschal II, written in 1103,

\footnotetext{
${ }^{109}$ For example, Theodor Schieffer, ed., Die Urkunden Lothars I und Lothars II, MGH DD Lo I/Lo II (Berlin, 1966), no. 92 (227): "pro criminalibus culpis, de quibus sacerdotibus et monachis non est licitum iudicare." The charter is cited by Bougard, Justice, 238, who observes that "quelques soupçons ont été formulés sur son authenticité," but the text is at least from the tenth century, judging by its transmission.

${ }^{110}$ Gerhoch of Reichersberg, De novitatibus, ed. Ernst Sackur, MGH Ldl 3, 3 vols. (Hannover, 1897), 3:295. Comparable statements: De aedificio dei, 147, 154, and 179; De investigatione Antichristi, 344-45; De Psalmis, 453. The best overview of Gerhoch's life and career is Peter Classen, Gerhoch von Reichersberg: Eine Biographie. Mit einem Anhang über die Quellen, ibre handschriftliche Überlieferung und ihre Chronologie (Wiesbaden, 1960); on this issue, see esp. 44-45, 236-37.

${ }^{111}$ Gerhoch, De Psalmis, 465; De investigatione Antichristi, 345.

${ }^{112}$ Liber de unitate ecclesiae conservanda, ed. Irene Schmale-Ott and Franz-Josef Schmale, Quellen zum Investiturstreit, 2 vols., Ausgewählte Quellen zur deutschen Geschichte des Mittelalters, Freiherr vom Stein-Gedächtnisausgabe 12b (Darmstadt, 1984), 280: "Sacerdotale enim iudicium non habet nisi gladium spiritus," 280; also the emphasis on bloodshed in comparing the court (curia) to bloodshed (cruor), 328 and 518.
}

Speculum 92/2 (April 2017) 
a theme that also recurred in his other works. ${ }^{113}$ None of these authors directly linked his arguments about the exercise of violence to the importance of advocates. Yet it is surely significant that all came from institutions where ecclesiastical advocacy was well established, and indeed Gerhoch of Reichersberg himself wrote a charter determining advocates' obligations and entitlements. ${ }^{114}$

Even more salient to this discussion is the case of Abbot Berengoz, or Benzo, of St. Maximin. In the years around 1100, Benzo wrote a lengthy sermon in which he emphasized (like Sigebert) that the church was best served by cooperation with people outside the church's hierarchy, so that "neither should the kingdom be separated from the priesthood, nor the priesthood from the kingdom." ${ }^{115}$ And he ferociously attacked the "heretics" who were seeking like madmen to disrupt this natural partnership. ${ }^{116}$ The sermon was not aimed at winning over the laity-it seems to have been intended for delivery in the monastery, as an expression of monastic ideas, for a monastic audience. ${ }^{117}$

Again, Benzo did not explicitly mention advocacy in his sermon. As it happens, however, we know that Benzo was the author of an entire series of forged advocacy charters for St. Maximin, briefly mentioned above. ${ }^{118}$ As already discussed, such charters are usually seen as attacks on aristocratic advocacy, which certainly formed an important part of St. Maximin's relations with the outside world, as its twelfth-century estate survey demonstrates in recording some of the dues payable to them. ${ }^{119}$ Yet when considered alongside Benzo's sermon, we would surely do better to consider his charters as documents setting out a partnership in line with his general concept of the church, divided between those

${ }^{113}$ Sigebert of Gembloux, Epistola Leodicensium adversus Paschalem papam, ed. Ernst Sackur, MGH Ldl 2 (Hannover, 1892), 451-64. For the general context, see now Mireille Chazan, "Entre l'école et le siècle: Sigebert de Gembloux, un historien engagé," in Sigebert de Gembloux, ed. JeanPaul Straus (Turnhout, 2015), 1-49.

${ }^{114}$ For Gerhoch's personal experience in drawing up charters, see Appelt, Die Urkunden Friedrichs I, vol. 2, no. 355 (195-97), and Classen, Gerhoch, no. 103 (375-76). For positive views at Hersfeld of advocates, see Lampert, Annales, 171 (1071); cf. however the same author's Libelli de institutione Herveldensis ecclesiae, ed. Holder-Egger, Lamperti Opera, for a less flattering account. On advocacy at Gembloux, see Alain Dierkens and Jean-Pierre Devroey, "L'avouerie dans l'Entre-Sambre-et-Meuse avant 1100," in Parisse, L'avouerie en Lotharingie, 43-94.

${ }^{115}$ Benzo, Libellus insignis de mysterio, PL 160:1006: "nec regnum a sacerdotio, nec sacerdotium separetur a regno." On the sermon, written at some point before Benzo's death c. 1126, see Klaus Krönert, "Helena, das Kreuz Christi und die Juden: Anmerkungen zu zwei Predigten des Urkundenfälschers Berengosus von St. Maximin (vor 1107-1125), De laude et inventione sanctae crucis und De mysterio ligni Domini," Kurttrierisches Jabrbuch 45 (2005): 57-90.

${ }^{116}$ Benzo, Libellus, PL 160:1006: “[P]roinde multum erras, o Christiane nimirum haeretice, qui more phreneticorum regnum et sacerdotium soles agitare phrenetice."

${ }^{117}$ As Krönert, "Helena, das Kreuz Christi und die Juden," concludes, partly based on the frequent references to "fratres," and partly on the sheer length of the text.

${ }^{118}$ Benzo's forged charters for St. Maximin are exhaustively discussed in Kölzer, Urkundenfälscbung. See above, 380 .

${ }^{119}$ Reiner Nolden, ed., Das Urbar der Abtei Sankt Maximin vor Trier, Rheinische Urbare 6 (Düsseldorf, 1999), for instance, 47, 56, 61, and 64.

Speculum 92/2 (April 2017) 
who are of the world and who act outside, and those who are of God and who act inside. ${ }^{120}$

This acceptance of lay collaboration with monastic life may seem entirely unproblematic when set out in this way. Nevertheless, it was rather less common in the west and south of the former Carolingian empire, as contemporaries themselves recognized. Gerhoch noted how things were "different in France," where churchmen had no qualms about dealing with violent punishment. ${ }^{121} \mathrm{He}$ made the point about bishops in particular, but in fact we can see evidence of a quite different attitude among monastic leaders too. A good illustration is provided by a writer active at around the same time as Sigebert and Benzo, Abbot Geoffrey of Vendôme (d. 1132). Abbot Geoffrey was far more alarmed by the idea of ecclesiastical matters coming before a secular court than by the involvement of office holders within the church in the exercise of justice, which never struck him as a problem. ${ }^{122}$ For Geoffrey and others like him, the best solution was for the church, and by implication monasteries and their monks, to deal with these issues itself: as he wrote in 1119 , liberty meant not being subjected to secular power. ${ }^{123}$

Like Benzo, Geoffrey had no hesitation in making recourse to forgeries to buttress his point when it came to his own institution at Vendôme, and indeed he was almost certainly responsible for the texts that claimed justice for the abbot's court, written around 1100, discussed above. ${ }^{124}$ But rather than devising texts that wrote the administration of justice by laymen into the monastery's distant past, as Benzo had done, Geoffrey's forgeries excluded those laymen altogether: matters were to be dealt with at the abbot's court (curia abbatis) alone. Little wonder, then, that Geoffrey fell out with many aristocratic patrons over their "unjust" actions. ${ }^{125}$

Perhaps, however, the most intriguing piece of evidence in this context is provided by a letter sent by Peter the Venerable, the famous abbot of Cluny, to Bernard of Clairvaux around 1124. Described by one historian as "an aggressive defense of traditional Cluniac practices," and well known for its candid comments about secular lordship, the letter also sheds important light on Peter's attitudes to justice and, unusually, makes direct reference to advocates. ${ }^{126}$ In response

\footnotetext{
${ }^{120}$ Benzo, Libellus, PL 160:1006: “quoniam in Ecclesia Dei . . . sic est ordo distinctus, ut in his quae sunt saeculi, et in his quae Dei, unus operetur foris et alius intus" (comparing the division of labor to that between bakers and fishermen).

${ }^{121}$ Gerhoch, De investigatione Antichristi, 345.

${ }^{122}$ Geoffrey of Vendôme, Oeuvres, ed. Gérard Giordanengo, Sources d'Histoire Médiévale (Turnhout, 1996), letter no. 161 (356-59): “Omnino enim injustum est et sacris canonibus ... penitus obviare videtur ut aecclesiastica causa seculari et peregrino judicio terminetur."

${ }^{123}$ Geoffrey of Vendôme, Oeuvres, letter no. 176 (404): "Aecclesia semper catholica, libera et casta esse debet. .. Libera quia seculari potestati non debet subici” (Geoffrey reused the formulation later, 454). See Foulon, Église, 458-65 (though with a focus on bishops).

${ }^{124}$ Exhaustively discussed in Meinert, "Fälschungen."

${ }^{125}$ Ibid., 302: "Unter Gottfrieds Leitung entbrennt ein heftiger Kampf von fast ununterbrochener Dauer gegen alle aussenstehenden Gewalten, weltliche sowohl wie geistliche."

${ }^{126}$ For the quotation, see Gillian K. Knight, The Correspondence between Peter the Venerable and Bernard of Clairvaux: A Semantic and Structural Analysis (Aldershot, 2002), 25. On Peter's attitudes to this lordship, see Gregory A. Smith, “'Sine rege, sine principe': Peter the Venerable on Violence in Twelfth-Century Burgundy,” Speculum 77/1 (2002): 1-33.
}

Speculum 92/2 (April 2017) 
to the Cistercian criticism that Cluniac monks were too involved in judicial business, Peter declared that neither reason nor any law prohibited monks from being accusers or agents in their own affairs, and that if monks were to own property, they needed to be able to defend it. Peter agreed advocates might play a rolebut only if they could be always available ("si tamen advocati semper adesse potuerint"). Otherwise it was better for monks to act than to lose the property. And Peter saw no reason at all why monks could not be judges in secular matters: would they not become the judges even of angels? ${ }^{127}$ It is this attitude that surely explains why there is so little trace of advocacy in the strongholds of Cluniacstyle monasticism. And it is this attitude that explains why monks inspired by Cluny, such as Abbot Isarn of Saint-Victor of Marseille (or at least the representation of him in his late eleventh-century Life), seemed to blur the line between secular and ecclesiastical behaviors by acting in certain ways like aristocrats-a point that had long been made by critics of the Cluny monks. ${ }^{128}$

In the light of this material, Senn's famous line seems to reflect variation in monastic attitudes towards aristocrats and the exercise of violent power as much as different legal or political structures. This variation was certainly linked to positions regarding Gregorian reform, itself deeply engaged with questions of legitimate violence. ${ }^{129}$ Geoffrey of Vendôme, for instance, was undoubtedly close to post-Gregorian papal circles-as demonstrated not least by the famous cycle of frescos he installed at Vendôme to welcome Pope Urban II in 1096-while the proximity of Cluniac monasticism to the wider reform movement is well known (and much discussed). ${ }^{130}$ Equally, many of the writers cited above-Sigebert, Benzo, and the author of the Liber de unitate, all emphatic on the importance for

${ }^{127}$ Peter the Venerable, The Letters of Peter the Venerable, ed. Giles Constable, 2 vols. (Cambridge, MA, 1967), vol. 1, no. 28: "Cur etiam a iudiciis arceantur, cum apostolus dicat, nescitis quoniam angelos iudicabimus? Quanto magis saecularia.”

${ }^{128}$ Cécile Caby, ed. and trans., Vie d'Isarn, abbé de Saint-Victor à Marseille, XIe siècle (Paris, 2010), e.g., 74. See also Michel Lauwers, "Mémoire des origines et idéologies monastiques: SaintPierre-des-Fossés et Saint-Victor de Marseille au XIe siècle," in La mémoire des origines dans les institutions médiévales, Mélanges de l'École française de Rome, Moyen Âge 115 (2003), 155-80; and Florian Mazel, “'L'invention d'une tradition': Les monastères Saint-Victor de Marseille et Saint-Gilles à la recherche du patronage de Pierre (XIe-XIIe siècles)," in Écrire son histoire: Les communautés régulières face à leur passé, ed. Nicole Bouter (Saint-Etienne, 2006), 337-67. Earlier critique: see Paolo Rossi, ed., Adalbéron di Laon, Carme per re Roberto, ca. 1030 (Pisa, 2011), 33-35.

${ }^{129}$ On monastic relations with the aristocracy in this period in the context of the wider Gregorian reform movement, crucial are a number of works by Florian Mazel: "Amitié et rupture de l'amitié: Moines et grands laïcs provençaux au temps de la crise grégorienne (milieu XI-milieu XII siècle)," Revue historique 307 (2005): 53-96; Féodalités: 888-1180 (Paris, 2010), 108; and "Monachisme et aristocratie aux Xe-XIe siècles: Un regard sur l'historiographie récente," in Meijns and Vanderputten, Ecclesia in medio nationis, 47-75. See also Dominique Iogna-Prat, Michel Lauwers, Florian Mazel, and Isabelle Rosé, eds., Cluny: Les moines et la société au premier âge féodal (Rennes, 2013), presenting "monachisme comme agent de transformation sociale" (7). On Gregorian reform and violence, see now Gerd Althoff, "Selig sind, die Verfolgung ausüben": Päpste und Gewalt im Hochmittelalter (Darmstadt, 2013).

${ }^{130}$ On these frescos, see Hélène Toubert, "Les fresques de la Trinité de Vendôme, un témoignage sur l'art de la réforme grégorienne," Cahiers de civilisation médiévale 26 (1983): 297-326. On Cluniac links to Gregorian reform, see the classic Herbert E. J. Cowdrey, The Cluniacs and the Gregorian Reform (Oxford, 1970).

Speculum 92/2 (April 2017) 
clerics and monks to avoid too close an involvement in judicial affairs-were also all ambivalent or even hostile to claims made by popes such as Gregory VII. Yet we should not oversimplify. Communities like Saint-Aubin and Reichenau could change their position in these larger conflicts depending on the local situation, especially the attitude of their diocesan bishop; moreover, many of Gregory VII's keenest lay supporters in Germany were themselves lay advocates. ${ }^{131}$

Rather than simply mapping advocacy onto the conflict swirling around the enhanced aspirations of the papacy, we should consider more closely the nature of the monastic traditions that held sway within these regions. This was precisely the topic of Kassius Hallinger's celebrated work on the distinction between the reform movements led by Cluny and Gorze. ${ }^{132}$ Hallinger in fact drew special attention to monastic advocacy as a key element of the distinction he was attempting to uncover, arguing that Gorze and Cluny had "an entirely different position in the question of advocacy." 133 Admittedly, his book was very much of its time, and its heartfelt plea for recognition of the cultural achievements of medieval Germany is best understood as a product of the 1950s. Few historians today would defend the exaggerated distinction it drew between supposedly homogenous reform groups, which are now increasingly seen instead as "informal associations of reformist agents." Yet such associations might well have worked along the grain of preexisting networks of like-minded monastic communities-much as, as we have seen, charters about advocacy circulated among neighboring and linked communities. ${ }^{134}$

And that there were broad "families" of Benedictine monastic practice in the decades around 1100 is difficult to deny, even if the contours were blurred, monks traveled between communities, and the groupings were seldom in conflict with one another. In particular, a persistent distinction between "Frankish" and "Aquitainian" monastic zones has long been acknowledged. ${ }^{135}$ To some extent

${ }^{131}$ I. S. Robinson, Eleventh-Centurv Germanv: The Swabian Chronicles (Manchester, 2008), 3032. On the lay support for Gregory VII in southern Germany, the classic work is Karl Schmid, "Adel und Reform in Schwaben," in Investiturstreit und Reichsverfassung, ed. Josef Fleckenstein, Vorträge und Forschungen 17 (Sigmaringen, 1973), 295-319.

${ }^{132}$ Kassius Hallinger, Gorze-Kluny: Studien zu den monastischen Lebensformen und Gegensätzen im Hochmittelalter, 2 vols. (Rome, 1950-51). Emphasis on Cluniac autonomy already from the tenth century and into the eleventh is standard in the specialist work: see Barbara Rosenwein, $\underline{R \text { hinoceros }}$ Bound: Clunv in the Tenth Centurv (Philadelphia, 1982); and Daniel Méhu, Paix et communautés autour de l'abbaye de Cluny (Xe-XVe siècles) (Lyon, 2001), who discusses at 264-66 and 433-35 the role of monks carrying out judicial activity exactly as justified by Peter the Venerable. For Gorze reform, see now Anne Wagner, L'abbaye de Gorze au XIe siècle: Contribution à l'histoire du monachisme bénédictin dans l'Empire (Turnhout, 2006).

${ }^{133}$ Hallinger, Gorze-Kluny, 1:573: “in der Vogteifrage wiederum eine gänzlich verschiedengeartete Haltung."

${ }^{134}$ For an up-to-date reevaluation of reform (stressing the traditions of individual houses), see Steven Vanderputten, Monastic Reform as Process: Realities and Representations in Medieval Flanders, 9001-1100 (Ithaca, 2013), and his Reform, Conflict, and the Shaping of Corporate Identities: Collected Studies on Benedictine Monasticism in Medieval Flanders, c. 1050-c. 1150, Vita Regularis (Berlin, 2013), with the quotation taken from xxv.

${ }^{135}$ Lin Donnat, "Les coutumes monastiques autour de l'an Mil," in Religion et culture autour de l'an Mil: Royaume capétien et Lotharingie, ed. Dominique Iogna-Prat and Jean-Charles Picard (Paris, 1990), 17-24, at 20, for the "zone franque' en opposition avec une zone 'aquitain." "Big-data"

Speculum 92/2 (April 2017) 
this was expressed in divergent liturgical preferences-whether monks went back to bed before Lauds, where palms were blessed on Palm Sunday-that may seem trivial to the modern observer. But Hallinger argued that, when taken together, they represented a distinctive kind of monastic "constitution"; and in any case, they also included differences in the monastery's relations with the outside world, mediated through the provost or deacon, that might have more of a direct bearing on the issue explored here. ${ }^{136}$ Senn's line corresponds to a striking degree with these variations in monastic custom; to that extent, it makes sense to see attitudes to advocacy as simply another element of a varying monastic world view.

What underpinned this variation is not easy to perceive. Language may have played a role here, yet it should be noted that Fleury was a key center for "Frankish" customs (and also, it may be added, had dealings with monastic advocates). ${ }^{137}$ That "Frankish" practices were generally more traditional suggests there may be a link to a relatively greater continuity of monastic experience in the east than in the west; alternatively, we may be dealing with underlying nuances in monastic practice that reached back into the early Middle Ages. After all, disagreements about the relation between monastic communities and secular authorities were already present in the Carolingian empire, with differences in opinions between ("Aquitainian," or rather Languedocian) Aniane and (Frankish) Corbie, notwithstanding imperial efforts to bring about greater uniformity. ${ }^{138}$

Yet in any case, the eleventh and twelfth centuries were periods of great change in how authority was exercised at the local, regional and supraregional level right across Europe, meaning that it cannot have been a simple question of tradition versus innovation. Everywhere across the Latin West, formal processes of justice were becoming more clearly identified and sought after as the source of profit and power; and there are signs, too, of a gradual shift away from punishments mediated through compensation to punishments violently inflicted upon the body. ${ }^{139}$

analysis of monastic charters also reveals zoning at a European-wide scale: see the preliminary findings of Nicolas Perreaux, "L'écriture du monde (I). Les chartes et les édifices comme vecteurs de la dynamique sociale dans l'Europe médiévale (VIIe-milieu du XIVe siècle)," Bulletin du centre d'études médiévales d'Auxerre 19/2 (2015) (online publication).

${ }^{136}$ Maria Hillenbrandt, "Le doyen à Cluny: Quelques remarques sur sa terminologie et son histoire," Annales de Bourgogne 72 (2000): 397-429.

${ }^{137}$ On Fleury's dealings with advocates, see forthcoming work by Philippe Depreux. Scott G. Bruce, Silence and Sign Language in Medieval Monasticism: The Cluniac Tradition, c. 900-1200 (Cambridge, UK, 2007), 93-96, has a helpful discussion of language barriers in monastic contexts.

${ }^{138}$ Foulon, Église, 68, talks of the "véritable cataclysme" experienced by the monasteries in the west of France; see also Dominique Barthélemy, Nouvelle histoire des Capétiens: 987-1214 (Paris, 2012), 87-88. For comparison, see the analysis of the relatively insignificant impact of the Vikings on the long-term networks of Stavelot provided by Schroeder, Les hommes. For the Carolingian-period disagreements, see Rutger Kramer, “ ‘. . . ut normam salutiferam cunctis ostenderet’: Représentations de l'autorité impériale dans la Vita Benedicti Anianensis et la Vita Adalhardi," in Normes et hagiographie dans l'Occident latin (IVe-XVIe siècle): Actes du colloque international de Lyon 4-6 octobre 2010, ed. Marie-Cécile Isaïa and Thomas Granier, Hagiologia 9 (Turnhout, 2014), 101-18; cf. Julian Hendrix, "La liturgie monastique avant Cluny: La contribution carolingienne," in Iogna-Prat et al., Cluny: Les moines, 129-36; and Donnat, "Les coutumes," 23.

139 On the Feudal Revolution see now Chris Wickham, "The 'Feudal Revolution' and the Origins of Italian City Communes," Transactions of the Royal Historical Society 24 (2014): 29-55. For the shift in practices of punishment, see Hans Hirsch, Die hohe Gerichtsbarkeit im deutschen Mittelalter

Speculum 92/2 (April 2017) 
These general developments interacted with what appear to be deep-rooted variations in the self-conception of monastic communities; and the way that these communities chose to address these changes in turn had significant implications for wider society.

\section{Conclusion}

In many ways, Abbot Hermann of Niederaltaich was rather old-fashioned when, in the middle of the thirteenth century, he justified the position of the monastic advocate. From the middle of the twelfth century, and with growing determination, German monastic communities began to take their justice back "in house" and to administer it through their own agents. For instance, in 1153 Abbot Wibald of Stavelot, who just a few years earlier had drafted a charter legitimating advocacy on the lands of Saint-Remi, persuaded Emperor Frederic I to cede the advocatia of Stavelot to himself as abbot, though with markedly limited long-term success. ${ }^{140}$ At Saint-Mihiel and at Reichenau, attention was increasingly shifting to the subordinated officers of the monastery: the lay provosts, the villici, and the ministeriales.

In German historiography, this process is often referred to as the emergence of the Schirmvogt ("protective advocate"), or indeed as "de-advocatization" (Entvogtung), and explained as part of the process of territorialization, itself part of the constitutional history of the Reich. ${ }^{141}$ Looked at comparatively, however, it could also be described as a shift in attitude on the part of monastic communities within the Reich, as they came into line with what had long been the normal arrangements elsewhere for the administration of justice and what was taken for granted by newer ascetic groups like the Cistercians. ${ }^{142}$ This was in part a monastic response to the growing emphasis on accountability, whose profile was rising almost everywhere in thirteenth-century Europe, reflected in the rise of a managerial class of bailiffs, provosts, and villici. ${ }^{143}$ Partly too, though, it was a reflection of the gradual embedding within German monastic cultures of ideas associated with Gregorian reform that emphasized institutional autonomy, making monastic advocacy increasingly anomalous.

(Darmstadt, 1958); more recently, Lotte Kéry, Gottesfurcht und irdische Strafe: Der Beitrag des mittelalterlichen Kirchenrechts zur Entstehung des öffentlichen Strafrecht (Cologne, 2006); and Harding, Medieval Law, 75.

${ }^{140}$ Appelt, Die Urkunden Friedrichs I, 1:74-75. For the lack of long-term success, see Schroeder, Les hommes.

${ }^{141}$ For example, Aubin, Entstehung, 435-38, for an appendix listing the acquisition of rights of advocacy by monasteries in the lower Rhine region (mostly in the thirteenth century).

142 Though even Cistercian communities in the empire could sometimes have advocates: see Sven Wichert, Das Zisterzienserkloster Doberan im Mittelalter (Berlin, 2000), 134-43; see also Penth, "Kloster- und Ordenspolitik."

${ }^{143}$ Eberhard Linck, Sozialer Wandel in klösterlichen Grundherrschaften des 11. bis 13. Jahrhunderts: Studien zu den familiae von Gembloux, Stablo-Malmedy und St. Trond (Göttingen, 1979). On accountability, see most recently John Sabapathy, Officers and Accountability in Medieval England, 1170-1300 (Oxford, 2014).

Speculum 92/2 (April 2017) 
We might therefore consider this Entvogtung as a kind of Europeanization in Robert Bartlett's sense, a process of gradual alignment in monastic values. ${ }^{144}$ This process of rolling back advocacy was, however, slow and seldom complete anywhere in the Reich before the thirteenth century. And it certainly did not mean that monastic advocacy had not left long-term political and social consequences. All the monasteries considered in this article-Reichenau, Saint-Mihiel, Glastonbury, Sant'Ambrogio, Saint-Aubin, and so on-were wealthy; and how, in what way, and by whom that wealth was harnessed had major consequences for the "architecture of power." It is unquestionable that the common acceptance by monasteries throughout the Reich before the middle of the twelfth century that an external figure was in some way desirable or at the very least appropriate for the legitimate performance of justice left an enduring mark on the political landscape, even after the assumption had faded away. For a crucial period, it had made monasteries into platforms for ambitious and well-connected laymen, stabilizing the political frameworks of these princes at a time when elsewhere in the Latin West north of the Alps centralizing authorities were gaining ground. ${ }^{145}$

The question of the relationship of principalities to monastic advocacy, still the main theme of research in the field, is therefore by no means itself illegitimate, and in no way has this article attempted to play down its importance. Its point is simply that we may be making it harder to understand this connection if we assume that the answer is to be found in one side of the relationship of monastic advocacy alone and assume a fundamental antagonism between the parties. Advocacy in the Reich was not simply a "legal" institution and cannot therefore be fully explained in these terms: it was a particular way of resolving a perennial problem of the intersection of law and religion, in both parties' interests. ${ }^{146}$ Evidence like Hermann of Niederaltaich's narrative, or indeed the scores of surviving charters of advocacy regulation from the eleventh to the thirteenth centuries, do not simply inform us about what aristocrats did: they reflect the monastic attitudes that effectively called this advocacy into existence while simultaneously calling its details into question.

This is not to replace one monocausal explanation with another: how the problem of monastic independence was resolved depended in part on the legal and social conditions of the wider society, and it might be fruitful to consider connections between the monastic concepts of justice that prevailed in the Reich around 1100 and other characteristics of the same region, such as the emergence of a high-status group that was technically unfree, the ministerials, though the con-

\footnotetext{
${ }^{144}$ Robert J. Bartlett, The Making of Europe: Conquest, Colonization and Cultural Change, 9501350 (London, 1993). See already, though for different reasons, Mayer, Fürsten, 197.

${ }^{145}$ E.g., Kohl, Konflikt und Wandel, 303: "Alle erfolgreichen Adelsfamilien im Südwesten des Reichs, fast alle bedeutenden Familien, die wir fassen können, hielten auf die eine oder andere Art Vogteien." See also Mayer, Fürsten, characterizing advocacy as "eine Möglichkeit, das politische Potential der materiellen Macht der Kirche für den Staat auszuwerten und nutzbar zu machen” (2). For further discussion, though from a different perspective, see Charles West, Reframing the Feudal Revolution: Social and Political Transformation between Marne and Moselle, c. 800-1100 (Cambridge, UK, 2013), 242-53.

${ }^{146}$ See here Nicolas Huyghebaert, "Pourquoi l'Église a-t-elle besoin des avoués?" in Parisse, L'avouerie en Lotharingie, 33-42.
} 
nections here may well be indirect. ${ }^{147}$ Yet instead of starting with the assumption that influence worked in just one direction, from the world to the monastery, we might at least entertain the possibility of two-way traffic. It may not be a coincidence that when Duke Godfrey of Lotharingia, a man brought up in a region where monastic advocacy was common, became the leader of the new Latin polity of Jerusalem, the title for which he apparently first reached was that of advocate. ${ }^{148}$

In short, the answer to the conundrum with which we began-why only monasteries in the Reich and the surrounding regions had advocates who, though outsiders, played a role in the internal administration of the monastic communities' judicial affairs-could be that only there did monks accept that such figures and such involvement might be necessary for the fulfillment of the monastic vocation in changing social and political conditions. That monastic attitudes could have had such important and enduring political implications reminds us of the urgency of bringing the historiography of religion and its development into much closer contact with the historiography of how power was exercised in Western Europe, in the twelfth century as at other times. ${ }^{149}$ To understand a society as dominated by the church and the aristocracy as medieval Europe was, and to understand the regional differences within it, we need to bring the study of monks and of their lay cousins together, for the dialectical relation between them was a major motor of change. And to appreciate how this motor worked, we may need, on occasion, to shift the scale of analysis. For what seems to be normal or even mundane in a local, regional, or national context can, if compared carefully and appropriately with circumstances elsewhere, turn out to offer important insights into medieval European society as a whole.

\footnotetext{
147 The best treatment of ministerials in English is Benjamin Arnold, German Knighthood 1050 1300 (Oxford, 1985); a recent German summary is provided by Werner Hechberger, Adel, Ministerialität und Rittertum im Mittelalter (Munich, 2004), 91-99. Ministerials could act as judges despite their status and were usually exempted from the jurisdiction of the advocate, so it is difficult to see an immediate connection. For French parallels, see Barthélemy, Nouvelle histoire, 212-23.

${ }^{148}$ See John France, "The Election and Title of Godfrey of Bouillon," Canadian Journal of History 18 (1983): 321-29; and for an update, John France, Victory in the East: A Military History of the First Crusade (Cambridge, UK, 1996), 357, with n. 71.

${ }^{149}$ The key argument of Florian Mazel, "Pouvoir aristocratique et Église aux Xe-XIe siècles: Retour sur la 'révolution féodale' dans l'oeuvre de Georges Duby," Médiévales 54 (2008): 137-52, in relation to the Feudal Revolution historiography. See more broadly Maureen C. Miller, "Religion Makes a Difference: Clerical and Lay Cultures in the Courts of Northern Italy, 1000-1300," American Historical Review 105 (2000): 1094-130. For an earlier period, Hans Hummer, Politics and Power in Early Medieval Europe: Alsace and the Frankish Realm, 600-1000 (Cambridge, UK, 2005), 8, arguing that early medieval monasteries should be seen "not simply as objects of aristocratic activity but as something integral to the structuring of power."
}

$\overline{\text { Charles West is Reader in History at the University of Sheffield, UK (e-mail: c.m.west@sheffield }}$ ac.uk)

Speculum 92/2 (April 2017) 